\title{
Perrierite-(Ce) from the Laacher See tephra, Eifel, Germany, and the modular character of the chevkinite group of minerals
}

\author{
Thomas Malcherek ${ }^{1}$ (1) Jochen Schlüter ${ }^{2} \cdot$ Christof Schäfer $^{3}$
}

Received: 17 September 2020 / Accepted: 4 December 2020 / Published online: 9 February 2021

(c) The Author(s) 2021

\begin{abstract}
Perrierite-(Ce) crystals from ejecta of the Laacher See volcano, Eifel, in Germany were studied by X-ray single-crystal diffraction and electron microprobe analysis. The composition and crystal structure of this sample is discussed in relation to the known properties of the chevkinite group minerals and related synthetic compounds. Taking into account the modular character of the chevkinite minerals, based on a rutile and a silicate module, the preferred formation of either the perrierite or the chevkinite structure type is correlated with the formal charge of the rutile and silicate modules. The rutile module is expected to carry a negative charge, compensated by a positive charge of the silicate module. On average, the charge modulus is observed to be larger for the chevkinite-type module stacking. It can drop to zero in perrierite-type structures rich in $\mathrm{Sr}$ or $\mathrm{Ca}$. In such cases, it is generally not expected to rise above two. The perrierite-(Ce) described in this study crystallizes in space group $C 2 / m$. The anisotropic oxygen and rare-earth element displacements observed in this crystal indicate a local domain structure of $P 2_{1} / a$ symmetry, when compared to the $P 2_{1} / a$ symmetry of the synthetic perrierite $\mathrm{La}_{4} \mathrm{Mg}_{2} \mathrm{Ti}_{3} \mathrm{O}_{8}\left(\mathrm{Si}_{2} \mathrm{O}_{7}\right)_{2}$.
\end{abstract}

Keywords Polytypes $\cdot$ Polysomatism $\cdot$ Rare-earth elements $\cdot$ Chevkinite $\cdot$ Perrierite

\section{Introduction}

The chevkinite-group minerals (CGM) are common accessory minerals in a wide range of rock types. The chemical composition of the CGM conforms to a standard formula $A_{4} B C_{2} D_{2} \mathrm{O}_{8}\left(\mathrm{Si}_{2} \mathrm{O}_{7}\right)_{2}$ (Macdonald et al. 2019). The $A$-sites host relatively large $(\mathrm{r}>1 \AA$ ) predominantly di- and trivalent cations, i.e., rare-earth elements (REE), $\mathrm{Ca}$ and $\mathrm{Sr}$. The REE content is dominated by the light REE (LREE) between La and Sm (Macdonald and Belkin 2002). While the A-sites are at least seven-coordinated by oxygen atoms, the remaining B-, C- and D-sites all have distorted octahedral coordination, hosting smaller cations with radii significantly below $1 \AA$. The site nomenclature of the CGM varies

Thomas Malcherek

thomas.malcherek@uni-hamburg.de

1 Mineralogisch-Petrographisches Institut, Universität Hamburg, Grindelallee 48, D-20146 Hamburg, Germany

2 CeNak - Mineralogisches Museum, Universität Hamburg, Grindelallee 48, D-20146 Hamburg, Germany

3 Gustav-Stresemann-Straße 34, D-74257 Untereisesheim, Germany across publications by different authors (see Macdonald et al. (2019) and Nagashima et al. (2020) for summaries). We follow the site nomenclature of Macdonald et al. (2019) here, but emphasize that the site occupancies of the B-, Cand D-sites are extremely variable. Defining the structural sites by their site populations is, therefore, rather ambiguous. We are going to use the following definition instead: the $\mathrm{BO}_{6}$ octahedra share all their corner oxygen atoms with $\mathrm{SiO}_{4}$ tetrahedra of the sorosilicate groups. The $\mathrm{CO}_{6}$ octahedra share two opposite corners with such silicate groups and the $\mathrm{DO}_{6}$ are not connected to $\mathrm{SiO}_{4}$ tetrahedra at all (Fig. 1).

The currently known CGM are subdivided into the chevkinite and perrierite structure types. In minerals of both types, space group symmetries $C 2 / m$ and $P 2_{1} / a\left(P 2_{1} / c\right)$ have been observed. Unit cell parameters $a, b$ and $c$ are generally similar, with $b$ showing the smallest variability across different compositions. While there is systematic variation of the unit cell edges with structure type as well, the most pronounced difference is seen in the $\beta$-angle. In the perrierite type, $\beta \approx 114^{\circ}$ and in the chevkinite type, $\beta \approx 100^{\circ}$ is observed.

Ito and Arem (1971) reported high-temperature transformations from synthetic perrierite-type compounds of 
composition $\mathrm{Pr}_{4} \mathrm{Mg}_{2} \mathrm{Ti}_{3} \mathrm{O}_{8}\left(\mathrm{Si}_{2} \mathrm{O}_{7}\right)_{2}$ and $\mathrm{Pr}_{4} \mathrm{Ni}_{2} \mathrm{Ti}_{3} \mathrm{O}_{8}\left(\mathrm{Si}_{2} \mathrm{O}_{7}\right)_{2}$ to a chevkinite-type structure around 1070 and $1060^{\circ} \mathrm{C}$, respectively, but the transformation appeared to be irreversible. Other compositions of perrierite do not transform to chevkinite at all, according to this study. Calvo and Faggiani (1974) synthesized $\mathrm{La}_{4} \mathrm{Mg}_{2} \mathrm{Ti}_{3} \mathrm{O}_{8}\left(\mathrm{Si}_{2} \mathrm{O}_{7}\right)_{2}$ with the perrierite structure as well as $\mathrm{Nd}_{4} \mathrm{Mg}_{2} \mathrm{Ti}_{3} \mathrm{O}_{8}\left(\mathrm{Si}_{2} \mathrm{O}_{7}\right)_{2}$ and $\mathrm{Nd}_{4} \mathrm{Co}_{2} \mathrm{Ti}_{3}$ $\mathrm{O}_{8}\left(\mathrm{Si}_{2} \mathrm{O}_{7}\right)_{2}$, both with the chevkinite crystal structure. All three compounds have been described in space group $P 2_{1} / a$, rather than $C 2 / \mathrm{m}$. Starting from a large set of synthetic compounds, Ito (1967) obtained an empirical expression for the formation of either the chevkinite or the perrierite structure based on the average ionic radii at the B, C and A-sites.

Ferraris et al. (2004) noted that the CGM are in fact modular materials, forming a polysomatic series. The modularity of the CGM is based on a rutile module and a silicate module, stacked along $c^{*}$. The rutile module is topologically identical to a (110) layer of the rutile structure (R-module). It contributes the $C_{2} D_{2} \mathrm{O}_{8}$ unit of the CGM formula. The other basic module is formed by the $A_{4} B\left(\mathrm{Si}_{2} \mathrm{O}_{7}\right)_{2}$ sorosilicate unit (S-module).

It is worthwhile to consider the charge balance of both modules separately. If both the C-and D-sites of the R-module are occupied by tetravalent cations like $\mathrm{Ti}^{4+}$, the module is formally charge neutral (as it would be in $\mathrm{TiO}_{2}$ ). If $\mathrm{D}$ is a trivalent metal cation and $\mathrm{C}$ is tetravalent, as for example in chevkinite-type polyakovite-(Ce), $(\mathrm{Ce}, \mathrm{Ca})_{4} \mathrm{MgCr}_{2}^{3+} \mathrm{Ti}_{2}$ $\mathrm{O}_{8}\left(\mathrm{Si}_{2} \mathrm{O}_{7}\right)_{2}$ (Popov et al. 2001), the R-module would carry two negative charges. The compensating positive charge of the S-layer mainly depends on the ratio of trivalent REE and divalent earth alkaline metal cations occupying the A-sites. For a 2:2 ratio and a divalent B-site occupancy, the $\mathrm{S}$-module would be charge neutral. For compensation of the negatively charged R-layer in polyakovite-(Ce), the REE/ $\mathrm{Ca}$ ratio has to be larger than one and/or a tri- or tetravalent cation has to at least partially substitute at the $\mathrm{B}$-site. In fact the ideal composition is Ca-free, $\mathrm{REE}_{4} \mathrm{MgCr}_{2}^{3+} \mathrm{Ti}_{2} \mathrm{O}_{8}\left(\mathrm{Si}_{2} \mathrm{O}_{7}\right)_{2}$ (Popov et al. 2001). On the other hand, perrierite-structured matsubaraite, $\mathrm{Sr}_{4} \mathrm{Ti}_{5} \mathrm{O}_{8}\left(\mathrm{Si}_{2} \mathrm{O}_{7}\right)_{2}$ (Miyajima et al. 2002), has its A-sites entirely occupied by a divalent cation. This is compensated by tetravalent $\mathrm{Ti}$ at the $\mathrm{B}$-site, yielding a zero module charge.

As is commonly the case in polysomatic series, the stacking of different modules determines the stoichiometry as well as the unit cell dimensions of the resulting compound. The chevkinite structure is formed by the sequence RSRSRS.... The perrierite-type structure is formed by RSRS'RSRS', where the S'-layer is shifted by a/2 with respect to the S-layer. Other polysomes have been synthesized, in particular the sequence RRSRRS... (Wang et al. 1995). In general, the minerals of the CGM are able to form polytypes due to their modular character. In fact chevkinite(Ce) and perrierite-(Ce) could be considered different polytypes of the same mineral species. The different topology of the interface between R- and S-modules resulting in both polytypes is shown in Fig. 1. While the RSRS sequence of chevkinite causes a staggered connectivity of $\mathrm{SiO}_{4}$ tetrahedra and $\mathrm{CO}_{6}$ octahedra along [010] at the module boundary, the shifted $\mathrm{S}$ '-modules of the perrierite sequence cause an eclipsed configuration of the $\mathrm{SiO}_{4}$ tetrahedra and of the A-cations on either side of the R-module. While a very large amount of compositional data for the CGM exists in the literature, detailed crystal structure data are not so common. In part, the lack of crystal structure data is due to the scarcity of good quality natural crystals, as the CGM frequently occur in the metamict or at least partially metamict state (Sokolova et al. 2004) and might also be subject to secondary chemical alterations due to this metamict state. To increase crystallinity, such samples often are annealed at temperatures of $750^{\circ} \mathrm{C}$ or higher (Sokolova et al. 2004; Stachowicz et al. (a)

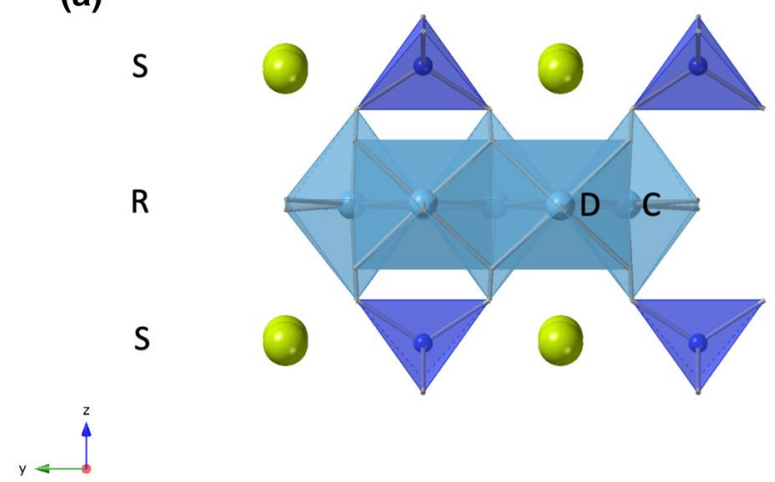

(b)

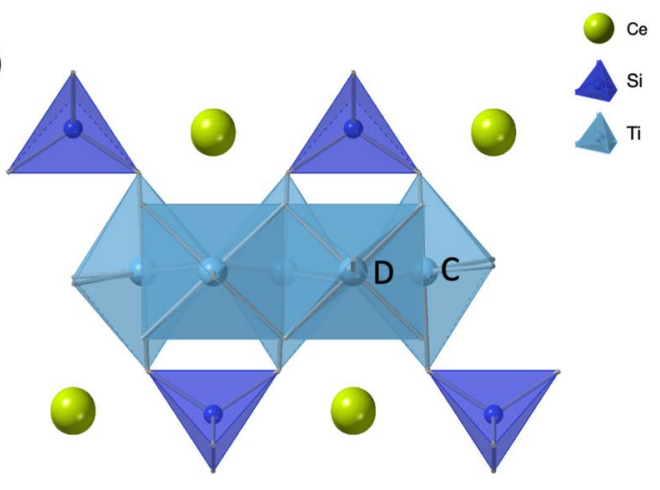

Fig. 1 Configuration of the R-module boundary in a) the perrierite structure type (this work), b) the chevkinite structure type (structure data from Sokolova et al. (2004)) 
2019b). This may lead to cation ordering, redox reactions or other transformation processes that are likely to render the crystals in a different state than that prior to metamictization. Hence, well crystallized, non-metamict natural samples and synthetic samples are needed to obtain reliable information about structural properties of well-equilibrated CGM. A detailed study of cation distribution in three non-metamict chevkinite-(Ce) samples has been published very recently (Nagashima et al. 2020). One aim of the present work is to identify possible mechanisms that could help to explain the empirically known compositional controls (Macdonald et al. 2019) over the formation of either the chevkinite- or perrierite-type structure in CGM.

\section{Experimental}

The sample material used in this work is from ejecta of the Laacher See volcano (LSV), which erupted $12.9 \mathrm{ka}$ ago (Schmitt et al. 2010) in the East-Eifel area, Rhineland-Palatinate, Germany. The sample was collected at the
In den Dellen quarry near Mendig, Germany. A needleshaped crystal of perrierite-(Ce), extending along [010] and of dark reddish-brown color has been measured using $\mathrm{X}$-ray single-crystal diffraction with a Nonius KappaCCD diffractometer equipped with graphite monochromated $\operatorname{MoK} \alpha$ radiation. Data collection and crystal details are given in Table 1. Pixel intensities were integrated using the Eval15 software package (Schreurs et al. 2010). Structure refinement was conducted using Jana2006 (Petřriček et al. 2014). Scattering functions for the uncharged atoms are used throughout. All structure diagrams have been prepared using CrystalMaker (Palmer 2015).

Three fragments of similar crystals from the same location were measured using a Cameca electron microprobe (Cameca SX 100) in wavelength-dispersive mode. An accelerating voltage of $15 \mathrm{kV}$ and a probe current of 20 $\mathrm{nA}$ were used. Standards used were andradite ( $\mathrm{Si} \mathrm{K} \alpha, \mathrm{Ca}$ $\mathrm{K} \alpha, \mathrm{Fe} \mathrm{K} \alpha), \mathrm{MnTiO}_{3}(\mathrm{Mn} \mathrm{K} \alpha, \mathrm{Ti} \mathrm{K} \alpha), \mathrm{ZrSiO}_{4}(\mathrm{Zr} \mathrm{L} \alpha)$, $\mathrm{Nb}_{2} \mathrm{O}_{5}(\mathrm{Nb} \mathrm{L} \alpha), \mathrm{Ta}_{2} \mathrm{O}_{5}(\mathrm{Ta} \mathrm{L} \alpha), \mathrm{UO}_{2}(\mathrm{U} \mathrm{M} \beta), \mathrm{MgO}(\mathrm{Mg}$ $\mathrm{K} \alpha)$, albite $(\mathrm{Na} \mathrm{K} \alpha), \mathrm{Al}_{2} \mathrm{O}_{3}(\mathrm{Al} \mathrm{K} \alpha)$, and $\mathrm{SrTiO}_{3}(\mathrm{Sr} \mathrm{L} \alpha)$. Standards for REE and Th consisted of five different oxide glasses ( $\mathrm{Y} \operatorname{L} \alpha, \mathrm{La} \operatorname{L} \alpha, \mathrm{Ce} \operatorname{L} \alpha, \operatorname{Pr} \operatorname{L} \beta, \operatorname{Nd} \operatorname{L} \beta, \operatorname{Sm~L} \beta, \mathrm{Gd}$
Table 1 Single-crystal diffraction details

\begin{tabular}{|c|c|}
\hline \multicolumn{2}{|l|}{ Crystal } \\
\hline Chemical formula (refined) & $\mathrm{Ca}_{1.55} \mathrm{Ce}_{2.45} \mathrm{Fe}_{0.86} \mathrm{Al}_{0.4} \mathrm{Ti}_{3.39} \mathrm{Nb}_{0.21} \mathrm{Zr}_{0.14} \mathrm{Si}_{4} \mathrm{O}_{22}$ \\
\hline Space group & $C 2 / m$ \\
\hline $\mathrm{a}(\AA)$ & $13.6348(8)$ \\
\hline $\mathrm{b}(\AA)$ & $5.6484(5)$ \\
\hline$c(\AA)$ & $11.7194(7)$ \\
\hline$\beta\left(^{\circ}\right)$ & $113.736(5)$ \\
\hline $\mathrm{V}\left(\AA^{3}\right)$ & $826.22(11)$ \\
\hline $\mathrm{Z}$ & 2 \\
\hline Radiation type & $\mathrm{X}$-ray, $\lambda=0.7107 \AA$ \\
\hline$\mu\left(\mathrm{mm}^{-1}\right)$ & 10.04 \\
\hline Crystal size (mm) & $0.04 \times 0.04 \times 0.4$ \\
\hline \multicolumn{2}{|l|}{ Data collection } \\
\hline Diffractometer & Four circle kappa diffractometer \\
\hline Absorption correction & Numeric \\
\hline $\mathrm{T}_{\min }, \mathrm{T}_{\max }$ & $0.16,0.71$ \\
\hline$\theta_{\max }\left({ }^{\circ}\right)$ & 35 \\
\hline \multicolumn{2}{|l|}{ No. of measured, } \\
\hline Independent and observed $[I>3 \sigma(I)]$ reflections & $22274,1963,1859$ \\
\hline$R_{\text {int }}$ & 0.031 \\
\hline \multicolumn{2}{|l|}{ Refinement } \\
\hline$R\left[F^{2}>3 \sigma\left(F^{2}\right)\right], w R\left(F^{2}>3 \sigma\left(F^{2}\right)\right), S$ & $0.026,0.079,1.42$ \\
\hline$R[$ all $], w R\left(F^{2}\right), S$ & $0.027,0.08,1.4$ \\
\hline No. of parameters & 104 \\
\hline$\Delta \rho_{\max }, \Delta \rho_{\min }\left(\mathrm{e} \AA^{-3}\right)$ & $1.7,-1.78$ \\
\hline Extinction coefficient & $3050(160)$ \\
\hline Extinction method & $\begin{array}{l}\text { B-C type } 1 \text { Lorentzian isotropic (Becker and } \\
\text { Coppens 1974) }\end{array}$ \\
\hline
\end{tabular}


$\mathrm{L} \beta$, Tb $\mathrm{L} \beta$, Dy $\mathrm{L} \beta$, Ho $\mathrm{L} \beta$, Dy $\mathrm{L} \beta$, Er $\mathrm{L} \beta, \operatorname{Tm} \mathrm{L} \alpha, \mathrm{Yb}$ $\mathrm{L} \alpha, \mathrm{Lu} \mathrm{L} \alpha$, Th $\mathrm{M} \alpha$ ). An electron backscattering image of a crystal section normal to the elongation direction indicates chemical zonation, with a brighter area at the center of the crystal, surrounded by a darker rim. This correlates with the obtained REE profile, which indicates higher $\mathrm{La}$ concentration at the rim and elevated concentrations of $\mathrm{Ce}$, $\mathrm{Nd}$ and $\mathrm{Sm}$ towards the core region.

\section{Results}

\section{Crystal structure refinement}

Structure refinement of a perrierite-(Ce) crystal converged to $\mathrm{R} 1=0.026$ for 1859 reflections above the $I>3 \sigma(I)$ intensity level (Table 1). Refined structural parameters are compiled in Tables 2 and 3. A cif-file is made available as Online Resource 1. A small volume fraction of the crystal is a twin domain, rotated by $180^{\circ}$ about $\mathbf{c}^{*}$, giving rise to some weak extra reflections (Online Resource 2). The domain boundary of such a twin can be associated with an R-layer (Fig. 2), as the twin axis is parallel to the layer stacking direction and the R-layer contains the twinoperation, disregarding minor distortions of the octahedra. It can be expected that this type of growth twinning is very common within the CGM, due to the resulting low energy of the twin boundary that does not alter the bond topology. Mashima et al. (2008) describe a microtwinned, orthorhombic polytype of rengeite, formed by a module sequence $\operatorname{SRS}_{T} \operatorname{RSRS}_{T} \ldots$, where $\mathrm{S}_{T}$ is the twin equivalent

Table 2 Positional parameters

\begin{tabular}{llllll}
\hline Site & Occupancy & $\mathrm{x}$ & $\mathrm{y}$ & $\mathrm{z}$ & $\mathrm{U}_{\text {eqv. }}\left(\AA^{2}\right)$ \\
\hline $\mathrm{A} 1$ & $0.578(3) \mathrm{Ce}, 0.422(3) \mathrm{Ca}$ & $0.235380(18)$ & 0 & $0.26580(2)$ & $0.01336(9)$ \\
$\mathrm{A} 2$ & $0.648(3) \mathrm{Ce}, 0.352(3) \mathrm{Ca}$ & $0.048295(16)$ & 0 & $0.745431(19)$ & $0.01378(8)$ \\
$\mathrm{B}$ & $0.857(12) \mathrm{Fe}, 0.143(12) \mathrm{Zr}$ & 0 & $1 / 2$ & $1 / 2$ & $0.00941(16)$ \\
$\mathrm{C}$ & $0.800(10) \mathrm{Ti}, 0.200(10) \mathrm{Al}$ & 0 & $0.24079(9)$ & 0 & $0.00945(15)$ \\
$\mathrm{D}$ & $0.895(5) \mathrm{Ti}, 0.105(5) \mathrm{Nb}$ & $0.27245(3)$ & 0 & $0.00245(4)$ & $0.00939(13)$ \\
$\mathrm{Si} 1$ & $\mathrm{Si}$ & $0.40975(5)$ & 0 & $0.73466(6)$ & $0.0077(2)$ \\
$\mathrm{Si} 2$ & $\mathrm{Si}$ & $0.16070(6)$ & 0 & $0.54682(7)$ & $0.0096(2)$ \\
$\mathrm{O} 1$ & $\mathrm{O}$ & $0.07212(12)$ & $0.2587(2)$ & $0.18279(13)$ & $0.0119(4)$ \\
O2 & $\mathrm{O}$ & $0.28919(11)$ & $0.2504(2)$ & $0.12308(12)$ & $0.0088(3)$ \\
O3 & $\mathrm{O}$ & $0.38403(17)$ & $0.2651(4)$ & $0.40804(18)$ & $0.0248(6)$ \\
O4 & $\mathrm{O}$ & $0.09357(16)$ & 0 & $-0.0100(2)$ & $0.0112(5)$ \\
O5 & $\mathrm{O}$ & $0.40810(15)$ & 0 & $0.00851(18)$ & $0.0088(5)$ \\
O6 & $\mathrm{O}$ & $0.4901(2)$ & 0 & $0.6675(3)$ & $0.0278(9)$ \\
O7 & $\mathrm{O}$ & $0.2866(2)$ & 0 & $0.6393(3)$ & $0.0313(9)$ \\
O8 & $\mathrm{O}$ & $0.13769(18)$ & 0 & $0.40334(19)$ & $0.0138(6)$ \\
\hline
\end{tabular}

Table 3 ADP harmonic parameters (in $\AA^{2}$ )

\begin{tabular}{lllllll}
\hline Site & $\mathrm{U}^{11}$ & $\mathrm{U}^{22}$ & $\mathrm{U}^{33}$ & $\mathrm{U}^{12}$ & $\mathrm{U}^{13}$ & $\mathrm{U}^{23}$ \\
\hline $\mathrm{A} 1$ & $0.01488(13)$ & $0.01412(13)$ & $0.01211(13)$ & 0 & $0.00649(9)$ & 0 \\
$\mathrm{~A} 2$ & $0.00956(12)$ & $0.02093(13)$ & $0.00998(12)$ & 0 & $0.00302(8)$ & 0 \\
$\mathrm{~B}$ & $0.0119(3)$ & $0.0096(2)$ & $0.0071(2)$ & 0 & $0.00423(16)$ & 0 \\
C & $0.0117(2)$ & $0.0089(2)$ & $0.0073(2)$ & 0 & $0.00340(15)$ & 0 \\
$\mathrm{D}$ & $0.0108(2)$ & $0.00751(19)$ & $0.00909(18)$ & 0 & $0.00315(13)$ & 0 \\
Si1 & $0.0079(3)$ & $0.0071(3)$ & $0.0073(3)$ & 0 & $0.0023(2)$ & 0 \\
Si2 & $0.0093(3)$ & $0.0124(3)$ & $0.0064(3)$ & 0 & $0.0024(2)$ & 0 \\
O1 & $0.0195(6)$ & $0.0063(5)$ & $0.0076(5)$ & $0.0007(4)$ & $0.0030(4)$ & $-0.0008(4)$ \\
O2 & $0.0099(5)$ & $0.0088(5)$ & $0.0071(5)$ & $0.0003(4)$ & $0.0027(4)$ & $0.0001(4)$ \\
O3 & $0.0280(8)$ & $0.0271(9)$ & $0.0179(7)$ & $0.0113(7)$ & $0.0080(6)$ & $-0.0044(7)$ \\
O4 & $0.0127(8)$ & $0.0085(7)$ & $0.0155(8)$ & 0 & $0.0068(7)$ & 0 \\
O5 & $0.0100(7)$ & $0.0087(7)$ & $0.0103(7)$ & 0 & $0.0045(6)$ & 0 \\
O6 & $0.0190(11)$ & $0.0531(19)$ & $0.0192(11)$ & 0 & $0.0138(9)$ & 0 \\
O7 & $0.0101(9)$ & $0.055(2)$ & $0.0228(12)$ & 0 & $-0.0030(8)$ & 0 \\
O8 & $0.0190(9)$ & $0.0171(9)$ & $0.0080(7)$ & 0 & $0.0058(7)$ & 0 \\
\hline
\end{tabular}




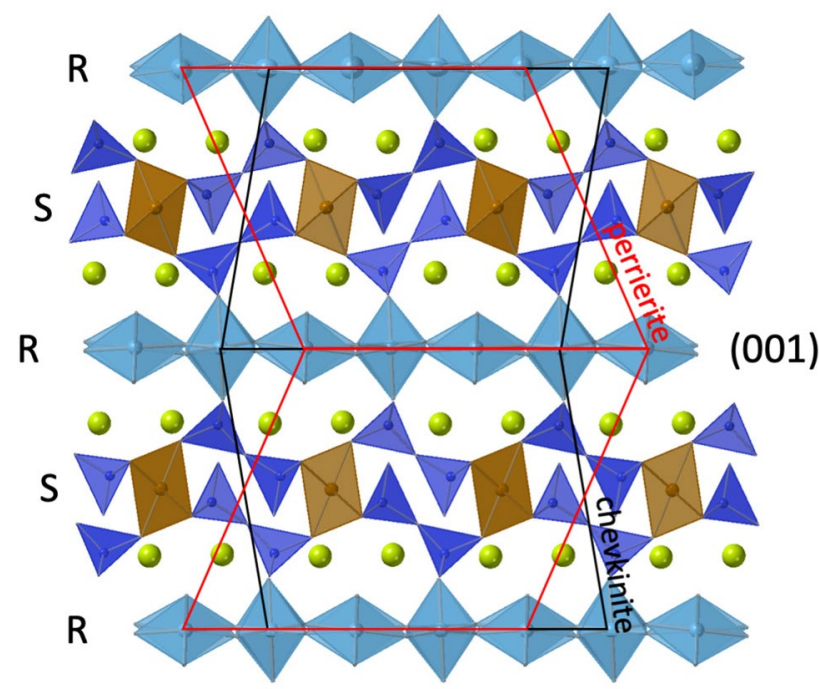

Fig. 2 The R-layer as twin boundary of the chevkinite and perrieritetype structures. Unit cell outlines of both polytype structures and their twin equivalents are indicated in black and red color, respectively. $\mathrm{SiO}_{4}$ tetrahedra are shown in blue, $\mathrm{BO}_{6}$ octahedra in brown, A-site cations in yellow and $\mathrm{C}$ and $\mathrm{D}$-site coordination polyhedra in light blue color

of $\mathrm{S}$. This orthorhombic structure is also found intergrown with monoclinic rengeite.

Reflections potentially violating the condition $h+k=2 n$ for C-centering are not observable by X-ray diffraction in perrierite-(Ce) from the LSV. Diffraction spots are sharp and the crystal shows no obvious signs of metamictization in spite of the significant Th content. This is not unexpected considering the relatively young age of these crystals.

To approximate the site scattering of the A-, B-, C- and D-sites, site population with the element pairs $\mathrm{Ca} / \mathrm{Ce}(\mathrm{A} 1$ and $\mathrm{A} 2$ ), $\mathrm{Fe} / \mathrm{Zr}(\mathrm{B}), \mathrm{Ti} / \mathrm{Al}(\mathrm{C})$ and $\mathrm{Ti} / \mathrm{Nb}(\mathrm{D})$ was refined, assuming full occupancy of all structural sites. Good agreement of the refined site occupancies with the results of the EMPA (Tables 4, 5) is obtained at the A- and D-sites. At the A1- and A2-sites, the Ce-scattering function serves as an approximation of average scattering by the dominant LREE $\mathrm{La}, \mathrm{Ce}, \mathrm{Pr}$ and Nd, with the concentrations of all other REE either close to or below the detection limit (Tables 4, 5). The A1-site is seven coordinated by oxygen atoms with A1-O distances ranging between 2.47 and $2.532 \AA$, with a mean distance of $2.511 \AA$, if we assume that bonds have to contribute a bond valence of at least $4 \%$ of the central cation charge (Brown 2002). There are three further A1-O distances (3.026 and $3.094 \AA$, to O4 and O7, respectively), that do not match this criterion (Table 6). Following the same definitions, A2 is coordinated by eight oxygen atoms at distances ranging between 2.431 and $2.680 \AA$ with a mean distance of $2.592 \AA$. Two more distant oxygens (O6)
Table 4 Electron microprobe analysis of perrierite crystal fragments in oxide wt $\%$. Iron content has been calculated as ferrous iron for all crystal fragments (in italics). The ferric and ferrous iron content for $60 \% \mathrm{Fe}^{3+}$ is given for the mean

\begin{tabular}{|c|c|c|c|c|}
\hline Oxide & wt\% (1) & $\mathrm{wt} \%$ (2) & wt\% (3) & Mean \\
\hline $\mathrm{SiO}_{2}$ & $20.76(10)$ & $21.18(22)$ & $20.74(18)$ & 20.89 \\
\hline $\mathrm{Al}_{2} \mathrm{O}_{3}$ & $3.38(4)$ & $3.38(12)$ & $3.38(12)$ & 3.38 \\
\hline $\mathrm{MgO}$ & $0.46(3)$ & $0.40(2)$ & $0.62(11)$ & 0.49 \\
\hline $\mathrm{CaO}$ & $7.65(24)$ & $8.22(38)$ & $6.14(26)$ & 7.34 \\
\hline $\mathrm{MnO}$ & $0.59(05)$ & $0.64(6)$ & $0.79(5)$ & 0.67 \\
\hline $\mathrm{Fe}_{2} \mathrm{O}_{3}$ & & & & 4.16 \\
\hline $\mathrm{FeO}$ & $6.20(13)$ & $5.90(19)$ & $6.63(24)$ & 2.50 \\
\hline $\mathrm{TiO}_{2}$ & $17.56(15)$ & $18.19(31)$ & $16.53(20)$ & 17.43 \\
\hline $\mathrm{ZrO}_{2}$ & $3.51(27)$ & $3.85(21)$ & $2.41(18)$ & 3.26 \\
\hline $\mathrm{Nb}_{2} \mathrm{O}_{5}$ & $1.75(17)$ & $1.43(9)$ & $1.92(20)$ & 1.7 \\
\hline $\mathrm{Ta}_{2} \mathrm{O}_{5}$ & $0.01(3)$ & $0.01(2)$ & 0.03 (3) & 0.02 \\
\hline $\mathrm{Y}_{2} \mathrm{O}_{3}$ & $0.27(3)$ & $0.13(9)$ & $0.23(6)$ & 0.21 \\
\hline $\mathrm{La}_{2} \mathrm{O}_{3}$ & $14.78(30)$ & $16.71(186)$ & $16.18(174)$ & 15.89 \\
\hline $\mathrm{Ce}_{2} \mathrm{O}_{3}$ & 17.05 (39) & $14.84(44)$ & $18.70(96)$ & 16.86 \\
\hline $\mathrm{Pr}_{2} \mathrm{O}_{3}$ & $0.83(7)$ & $0.57(12)$ & 0.87 (19) & 0.76 \\
\hline $\mathrm{Nd}_{2} \mathrm{O}_{3}$ & 1.54 (13) & $0.92(38)$ & $1.64(58)$ & 1.37 \\
\hline $\mathrm{Sm}_{2} \mathrm{O}_{3}$ & $0.05(4)$ & $0.02(3)$ & $0.05(5)$ & 0.04 \\
\hline $\mathrm{Gd}_{2} \mathrm{O}_{3}$ & $0.08(4)$ & $0.04(3)$ & $0.05(4)$ & 0.06 \\
\hline $\mathrm{Dy}_{2} \mathrm{O}_{3}$ & 0.02 (3) & $0.02(3)$ & $0.04(4)$ & 0.03 \\
\hline $\mathrm{Ho}_{2} \mathrm{O}_{3}$ & $0.02(3)$ & $0.03(4)$ & $0.02(3)$ & 0.02 \\
\hline $\mathrm{Er}_{2} \mathrm{O}_{3}$ & $0.01(2)$ & 0.00 & $0.01(2)$ & 0.01 \\
\hline $\mathrm{Yb}_{2} \mathrm{O}_{3}$ & 0.07 (2) & $0.04(3)$ & $0.05(3)$ & 0.05 \\
\hline $\mathrm{Lu}_{2} \mathrm{O}_{3}$ & $0.02(3)$ & $0.02(2)$ & $0.01(1)$ & 0.02 \\
\hline $\mathrm{UO}_{2}$ & $0.02(2)$ & $0.02(2)$ & $0.01(2)$ & 0.02 \\
\hline $\mathrm{ThO}_{2}$ & 0.99 (16) & $0.69(21)$ & 0.99 (46) & 0.89 \\
\hline Total & 97.62 & 97.25 & 98.04 & 98.07 \\
\hline points & 14 & 10 & 20 & \\
\hline
\end{tabular}

at $2.976 \AA$ contribute a little less than $4 \%$ to the central cation charge. The refined $\mathrm{Ca}$ occupancy is slightly higher at the A1-site than at A2 (Table 2). The refinement results also confirm that $\mathrm{Ti}$ and $\mathrm{Nb}$ populate the $\mathrm{D}$-site. Initial refinement of the B-site occupancy was attempted with $\mathrm{Fe}$ as the only scatterer. This yielded smaller displacement parameters than for the other octahedrally coordinated cations, indicating the additional presence of a stronger scatterer at the site. The B-site is coordinated by two opposite oxygen ligands at 2.021 and by four oxygen ligands at $2.129 \AA$ distance in a distorted octahedron. The average bond length of $2.093 \AA$ is smaller than expected for entirely ferrous iron, but too large for entirely ferric iron population. It is, however, well suited for $\mathrm{Zr}^{4+}$. Mixed occupancy by the pair $\mathrm{Fe}$ and $\mathrm{Zr}$ slightly lowered $\mathrm{R} 1$ and rendered $\mathrm{B}$-site displacement parameters similar to those obtained at the $\mathrm{C}$ - and $\mathrm{D}$-sites. 
Table 5 Mean chemical composition of perrierite-(Ce) crystal fragments 1,2 and 3 in apfu, calculated on the basis of 22 anions. Results of the site occupancy refinement from X-ray diffraction are given for comparison. The final two rows detail the REE content. The total content of other, heavier REE does not amount to more than 0.02 apfu

\begin{tabular}{|c|c|c|c|c|c|}
\hline & \multicolumn{2}{|l|}{ R-module } & \multicolumn{3}{|l|}{ S-module } \\
\hline & $\mathrm{D}$ & $\mathrm{C}$ & $\mathrm{A}$ & $\mathrm{B}$ & \\
\hline$\langle$ EMPA $\rangle$ & $\left(\mathrm{Ti}_{1.85} \mathrm{Nb}_{0.15}\right)_{\sum 2.0}$ & $\left(\mathrm{Ti}_{0.66} \mathrm{Al}_{0.76} \mathrm{Mg}_{0.14} \mathrm{Mn}_{0.11} \mathrm{Zr}_{0.30}\right)_{\Sigma 1.97} \mathrm{O}_{8}$ & $\left(\mathrm{Ca}_{1.51} \mathrm{REE}_{2.48} \mathrm{Th}_{0.04}\right)_{\sum 4.03}$ & $\left(\mathrm{Fe}_{0.4}^{2+} \mathrm{Fe}_{0.6}^{3+}\right)_{\Sigma 1.0}$ & $\left(\mathrm{Si}_{2} \mathrm{O}_{7}\right)_{2}$ \\
\hline XRD & $\left(\mathrm{Ti}_{1.79} \mathrm{Nb}_{0.21}\right)_{\sum 2.0}$ & $\left(\mathrm{Ti}_{1.6} \mathrm{Al}_{0.4}\right)_{\sum 2.0} \mathrm{O}_{8}$ & $\left(\mathrm{Ca}_{1.55} \mathrm{Ce}_{2.45}\right)_{\sum 4.0}$ & $\left(\mathrm{Fe}_{0.86} \mathrm{Zr}_{0.14}\right)$ & $\left(\mathrm{Si}_{2} \mathrm{O}_{7}\right)_{2}$ \\
\hline$\langle\mathrm{EMPA}\rangle_{\text {corr }}$ & $\left(\mathrm{Ti}_{1.85} \mathrm{Nb}_{0.15}\right)$ & $\left(\mathrm{Ti}_{0.66} \mathrm{Al}_{0.76} \mathrm{Zr}_{0.16} \mathrm{Mg}_{0.14} \mathrm{Fe}_{0.14}^{3+} \mathrm{Mn}_{0.11}\right) \mathrm{O}_{8}$ & $\left(\mathrm{Ca}_{1.51} \mathrm{REE}_{2.48} \mathrm{Th}_{0.04}\right)$ & $\left(\mathrm{Fe}_{0.4}^{2+} \mathrm{Fe}_{0.46}^{3+} \mathrm{Zr}_{0.14}\right)$ & $\left(\mathrm{Si}_{2} \mathrm{O}_{7}\right)_{2}$ \\
\hline$\overline{\mathrm{REE}}$ & $\mathrm{Y}$ & $\mathrm{La}$ & $\mathrm{Ce}$ & $\operatorname{Pr}$ & $\mathrm{Nd}$ \\
\hline$\langle$ EMPA $\rangle$ & 0.02 & 1.12 & 1.18 & 0.05 & 0.09 \\
\hline
\end{tabular}

Table 6 Bond valences of perrierite-(Ce)

\begin{tabular}{|c|c|c|c|c|c|c|c|c|c|c|c|c|c|}
\hline & A1 & & A2 & & B & & $\mathrm{C}$ & & $\mathrm{D}$ & & Sil & $\mathrm{Si} 2$ & \\
\hline & $\mathrm{Ce}_{0.58}$ & $\mathrm{Ca}_{0.42}$ & $\mathrm{Ce}_{0.65}$ & $\mathrm{Ca}_{0.35}$ & $\mathrm{Fe}_{0.86}$ & $\mathrm{Zr}_{0.14}$ & $\mathrm{Ti}_{0.8}$ & $\mathrm{Al}_{0.2}$ & $\mathrm{Ti}_{0.9}$ & $\mathrm{Nb}_{0.1}$ & $\mathrm{Si}$ & $\mathrm{Si}$ & $\Sigma_{\mathrm{o}}$ \\
\hline \multirow[t]{2}{*}{$\mathrm{O} 1$} & 0.38 & 0.23 & 0.32 & 0.19 & & & 0.66 & 0.43 & & & 0.98 & & 2.19 \\
\hline & $\times 2$ & & $\times 2$ & & & & $\times 2$ & & & & $\times 2$ & & \\
\hline \multirow[t]{2}{*}{$\mathrm{O} 2$} & 0.37 & 0.23 & 0.34 & 0.20 & & & & & $0.70,0.66$ & $0.91,0.86$ & & & 2.00 \\
\hline & $\times 2$ & & $\times 2$ & & & & & & $\times 2$ & & & & \\
\hline \multirow[t]{2}{*}{$\mathrm{O} 3$} & 0.35 & 0.22 & 0.24 & 0.15 & 0.37 & 0.58 & & & & & & 0.97 & 1.87 \\
\hline & $\times 2$ & & $\times 2$ & & $\times 4$ & & & & & & & $\times 2$ & \\
\hline \multirow[t]{2}{*}{$\mathrm{O} 4$} & 0.09 & 0.06 & 0.24 & 0.15 & & & $0.79 \times 2$ & $0.51 \times 2$ & 0.22 & 0.28 & & & 1.90 \\
\hline & & & & & & & $\times 2$ & & & & & & \\
\hline \multirow[t]{2}{*}{ O5 } & & & & & & & $0.68 \times 2$ & $0.44 \times 2$ & 0.98 & 1.27 & & & 2.27 \\
\hline & & & & & & & $\times 2$ & & & & & & \\
\hline \multirow[t]{2}{*}{ O6 } & 0.03 & 0.02 & $0.11 \times 2$ & $0.07 \times 2$ & 0.49 & 0.78 & & & & & 1.11 & & 1.83 \\
\hline & & & $\times 2$ & & $\times 2$ & & & & & & & & \\
\hline \multirow[t]{2}{*}{$\mathrm{O} 7$} & 0.08 & 0.05 & & & & & & & & & 1.07 & 1.01 & 2.08 \\
\hline & $\times 2$ & & & & & & & & & & & & \\
\hline O8 & 0.42 & 0.26 & 0.47 & 0.29 & & & & & & & & 1.12 & 1.88 \\
\hline$\sum_{M}$ & 2.90 & 1.80 & 2.73 & 1.66 & 2.46 & 3.88 & 4.26 & 2.76 & 3.92 & 5.09 & 4.14 & 4.07 & \\
\hline
\end{tabular}

Site population of the C-site is more complicated, as this site is expected to accommodate the remaining cation species $\mathrm{Al}, \mathrm{Mg}$ and $\mathrm{Mn}$, in addition to Ti not accommodated at the D-site, as well as $\mathrm{Zr}$ and Fe not accommodated at the B-site. The scattering power significantly decreases in the sequence from $\mathrm{Zr}$ to $(\mathrm{Ti}, \mathrm{Mn}, \mathrm{Fe})$ to $(\mathrm{Mg}, \mathrm{Al})$. This renders site occupancy by the pair Ti/Al less comparable to the results of the EMPA than the refined site occupancies at the $\mathrm{A}$ and $\mathrm{D}$ positions. Assuming uncharged atoms and ignoring the different $\theta$-decays of the individual scattering functions, the total electron count of 40.4 for the refined $\mathrm{Ti}$ and $\mathrm{Al}$ population is only $1 \%$ smaller than the electron count obtained by EMPA (40.83) from the elements attributed to the C-site (Tab. 5). If we consider that the $\mathrm{Zr}$ occupancy at the B-site is 0.14 apfu from structure refinement, corresponding $\mathrm{Fe}$ substitution for $\mathrm{Zr}$ has to be considered at the C-site. This would yield an electron count of 38.87 at the $\mathrm{C}$-site, $4 \%$ smaller than the refined site scattering.

The displacement parameters of several oxygen atoms (O1, O3, O6, O7), but also those of the A-cation sites are unusually large and anisotropic (Table 3 ). This is not due to thermal displacement, but an indication of local distortions from the $C 2 / m$ space group symmetry, as will be discussed in section Space group symmetry of perrierite-(Ce).

\section{Chemical composition, Fe oxidation state and module charge}

In terms of chemical composition, the three crystal fragments are bordering on perrierite-(La), but $\mathrm{Ce}$ is still the 
dominant REE in two of the fragments. Comparing with table S5 of Macdonald et al. (2019), the perrierite is below average in $\mathrm{Mg}, \mathrm{Al}, \mathrm{Pr}$ and $\mathrm{Nd}$ contents, while it is comparatively rich in $\mathrm{Ca}, \mathrm{Nb}$, and $\mathrm{Zr}$. Knowledge of the $\mathrm{Fe}$ oxidation state of the perrierite crystals is important to estimate their module charge. Macdonald et al. (2019) compile the known Mössbauer studies of the CGM. The $\mathrm{Fe}^{3+}$ contents found in these 13 samples range between 18 and $61 \%$, showing that CGM with purely ferrous iron are at least not very common. Stachowicz et al. (2019a) determined a $\mathrm{Fe}^{3+}$ $/ \mathrm{Fe}^{2+}$ ratio of $1.84 / 1.0$ or $65 \% \mathrm{Fe}^{3+}$ in a particularly $\mathrm{Nb}$ rich chevkinite-(Ce) by X-ray photoelectron spectroscopy. Nagashima et al. (2020) report $\mathrm{Fe}^{3+}$ contents of 34, 59 and $61 \%$ for three chevkinite-(Ce) samples studied by Mössbauer spectroscopy. The reported $\mathrm{Fe}^{3+}$ content for perrierite-(La), which also originates from the LSV, is 60\% (Chukanov et al. 2012b). In the present sample, the bond valence sum (BVS) at the $\mathrm{B}$-site indicates at least partial substitution of $\mathrm{Fe}^{2+}$ by $\mathrm{Fe}^{3+}$ too (Table 6). We, therefore, assume that a relative $\mathrm{Fe}^{3+}$ content of $60 \%$ is reasonable. This also avoids unphysical overpopulation of the A and Si cation sites (Table 5) when calculating the empirical composition based on 22 oxygen anions.

It is instructive to compare the formal charges of the two modules. As the R-module contains substantial amounts of di- and trivalent cations and not enough pentavalent $\mathrm{Nb}$ to compensate for this, it is expected to be negatively charged. For the combined composition given in the third row of Table 5, the R-module can be attributed a formal charge of -1.37 , with the $\mathrm{S}$-module carrying a corresponding positive charge. Calculation of this module charge crucially depends on the particular configuration of metal cations and on their oxidation state and is, therefore, associated with an estimated uncertainty of $10 \%$. If for example, we assume $\mathrm{Fe}^{2+}$ at the $\mathrm{C}$-site, the $\mathrm{R}$-module charge would become -1.57. On the other hand, if $\mathrm{Mg}$ is relocated to the B-site and replaced by $\mathrm{Fe}^{3+}$, the module charge would become -1.23 .

\section{R-module octahedral distortions and site occupancy}

The D-site of perrierite exhibits a strongly distorted oxygen coordination, with a short $\mathrm{D}-\mathrm{O}$ bond of $1.822 \AA$ and an opposite long D-O distance of $2.384 \AA$. Short metal-oxygen bond distances, i.e., those significantly below the sum of the respective Shannon-radii, are typical of early transition metal cations $\mathrm{Ti}^{4+}$ and $\mathrm{Nb}^{5+}$, that frequently give rise to the formation of compounds and minerals (e.g., titanite, macedonite, natisite, $\mathrm{KNbO}_{3}, \mathrm{LiNbO}_{3}$ ) with ordered arrangements of short $\mathrm{Ti}=\mathrm{O}$ or $\mathrm{Nb}=\mathrm{O}$ bonds. The distortion in perrierite has been explained as a result of repulsion away from the closest A-site cations (Gottardi 1960; Stachowicz et al. 2014). The respective D-A distances are $3.322 \AA$ for D-A1 and $3.317 \AA$ for D-A2 in the present refinement. If the D-cation would be located at the center of its coordination polyhedron, these distances would reduce to $3.207 \AA$ and $3.147 \AA$, respectively. By contrast, in chevkinite-(Ce) in space group $C 2 / m$ the two D-sites, e.g., M3 and M4 (Sokolova et al. 2004), are located at special Wyckoff-positions $2 \mathrm{a}$ and $2 \mathrm{~b}$ and consequently $\mathrm{Ti}$ at this site cannot displace parallel [100] in this space group symmetry. The distances Ti3-Ce 1 and Ti2-Ce 2 are 3.223 and $3.183 \AA$ in this case, only marginally longer than the equivalent Ti-Ce distances in perrierite-(Ce) for Ti assumed at the center position. Stachowicz et al. (2014) argue that in chevkinite-(Ce) the shortest Ce-Ti distances are trans-oriented with respect to the R-module, while they are cis-oriented in the perrierite structure, causing the shift of the D-site cation by repulsion. Following the same line of reasoning some other distortions of the R-module in chevkinite can be explained too. The $\mathrm{DO}_{6}$-octahedra are slightly tilted in the chevkinite structure, as the trans-standing oxygen ligands are pulled towards the respective A-site cations above or below them, while this tilting force is absent in perrierite with its symmetrical arrangement of A-cations above and below each R-module (Fig. 1). The slight kinking of the $\mathrm{CO}_{6}$ chains parallel [010] in the chevkinite type can be similarly explained by the antisymmetrical interaction with the A-site cations. Regardless of these distortive effects based on nearest-neighbor attractive and next nearest-neighbor repulsive forces, the particularly strong distortion of the D-site coordination in the perrierite type is not likely to be entirely due to repulsive forces between the cations. In such a scenario, the ions would act like hard spheres and the deformation would propagate along the $\mathrm{Ti}-\mathrm{O}$ bond, distorting the octahedron, rather than primarily displacing its central ion and forming a very short $\mathrm{Ti}-\mathrm{O}$ bond. This particular behavior is promoted by the electronic properties of the $\mathrm{Ti}$ and $\mathrm{Nb}$ cations occupying this site. Gueho et al. (1995) took this into account by placing the Jahn-Teller active $\mathrm{Mn}^{3+}$ cation onto the D-site in the perrierite-type $\mathrm{La}_{4} \mathrm{Mn}_{5} \mathrm{O}_{8}\left(\mathrm{Si}_{2} \mathrm{O}_{7}\right)_{2}$ and $\mathrm{Mn}^{4+}$ onto the $\mathrm{C}$-site, thereby reversing the conventional distribution of formal charges inside the R-module.

\section{Comparison with other CGM}

Table 7 compares the unit cell parameters of the LSV sample with those of CGM and synthetic chevkinites and perrierites from the literature. Apart from the apparent difference in $\beta$ -angle between the perrierite and the chevkinite-type phases, the $a$ parameter ranges between 13.3 and $13.6 \AA$ for the chevkinite-type structures, while it is slightly larger, between 13.55 and $14 \AA$ for the perrierite type. The difference is more pronounced for the $c$ parameter, which ranges between 10.5 and 11.4 for the chevkinites and between 11.6 and 12 for the perrierite-type phases. The transformation matrix suitable to convert from the perrierite unit cell setting to that of chevkinite is $\left[\begin{array}{lll}-1 & 0 & 0\end{array}\right]\left[\begin{array}{lll}0 & -1 & 0\end{array}\right]\left[\begin{array}{lll}1 / 2 & 0 & 1\end{array}\right]$ (by rows). The 
Table 7 Comparison of CGM and isostructural synthetic compounds. References: 1. Stachowicz et al. (2014) , 2. Ito and Arem (1971), 3. Calvo and Faggiani (1974), 4. Miyajima et al. (2002), 5. Yang et al. (2012), 6. Miyajima et al. (2001), 7. Chukanov et al. (2012b),
8. Sokolova et al. (2004), 9. Popov et al. (2001), 10. Chen et al. (1995), 11. Chen et al. (1996), 12. Xu et al. (2008), 13. Chukanov et al. (2012a), 14. Chen et al. (1994), 15. Gueho et al. (1995), 16. Nagashima et al. (2020) 17. Gottardi (1960), Ito (1967)

\begin{tabular}{|c|c|c|c|c|c|c|c|c|c|}
\hline Name/formula & $\mathrm{RG}$ & $\mathrm{a}(\AA)$ & $\mathrm{b}(\AA)$ & $c(\AA)$ & $\beta\left[^{\circ}\right]$ & $\mathrm{V}\left(\AA^{3}\right)$ & $\mathrm{d}_{(001)}(\AA)$ & Charge & Ref. \\
\hline \multicolumn{10}{|l|}{ Perrierite } \\
\hline Perrierite-(Ce) & $C 2 / m$ & $13.6348(8)$ & $5.6484(5)$ & $11.7194(7)$ & $113.736(5)$ & $826.22(11)$ & 10.728 & 1.37 & This work \\
\hline $\mathrm{Pr}_{4} \mathrm{Mg}_{2} \mathrm{Ti}_{3} \mathrm{Si}_{4} \mathrm{O}_{22}$ & $P 2_{1} / a$ & $13.57(1)$ & $5.643(3)$ & $11.66(1)$ & $113.1(1)$ & $822(2)$ & 10.725 & 1.95 & 2 \\
\hline $\mathrm{Pr}_{4} \mathrm{Ni}_{2} \mathrm{Ti}_{3} \mathrm{Si}_{4} \mathrm{O}_{22}$ & $P 2_{1} / a$ & $13.57(2)$ & $5.655(3)$ & $11.70(1)$ & $113.34(4)$ & $825(1)$ & 10.743 & 2.0 & 2 \\
\hline Perrierite-(Ce) & $C 2 / m$ & 13.59 & 5.61 & 11.61 & 113.28 & 813.1 & 10.665 & 0.93 & 17 \\
\hline Perrierite-(La) & $P 2_{1} / a$ & $13.668(1)$ & $5.6601(6)$ & $11.743(1)$ & $113.64(1)$ & $832.2(2)$ & 10.758 & 1.62 & 7 \\
\hline $\mathrm{La}_{4} \mathrm{Mn}_{5} \mathrm{Si}_{4} \mathrm{O}_{22}$ & $C 2 / m$ & $14.024(2)$ & $5.571(2)$ & $11.703(2)$ & $114.34(4)$ & $833.1(4)$ & 10.663 & 2.0 & 15 \\
\hline $\mathrm{La}_{4} \mathrm{Mg}_{2} \mathrm{Ti}_{3} \mathrm{Si}_{4} \mathrm{O}_{22}$ & $P 2_{1} / a$ & $13.818(4)$ & $5.677(2)$ & $11.787(6)$ & $113.85(3)$ & $845.6(3)$ & 10.781 & 2.0 & 3 \\
\hline $\mathrm{La}_{4} \mathrm{Mg}_{2} \mathrm{Ti}_{3} \mathrm{Si}_{4} \mathrm{O}_{22}$ & $P 2_{1} / a$ & $13.786(4)$ & $5.6766(9)$ & $11.791(3)$ & $113.88(2)$ & 843.7 (4) & 10.782 & 1.96 & 2 \\
\hline Perrierite-(Ce) & $C 2 / m$ & $13.815(1)$ & $5.668(1)$ & $11.842(1)$ & $113.843(3)$ & $848.18(4)$ & 10.831 & 1.22 & $1^{*}$ \\
\hline Rengeite & $P 2_{1} / a$ & $13.97(1)$ & $5.675(7)$ & $11.98(1)$ & $114.26(8)$ & $866(2)$ & 10.922 & 0.45 & $6^{\dagger}$ \\
\hline Hezuolinite & $C 2 / m$ & $13.973(3)$ & $5.694(1)$ & $11.988(2)$ & $114.10(1)$ & $871.3(1)$ & 10.943 & 0.72 & 5 \\
\hline Matsubaraite & $P 2_{1} / a$ & $13.850(2)$ & $5.631(2)$ & $11.892(1)$ & $114.14(1)$ & $846.3(3)$ & 10.835 & 0 & 4 \\
\hline \multicolumn{10}{|l|}{ Chevkinite } \\
\hline $\mathrm{Nd}_{4} \mathrm{Mg}_{2} \mathrm{Ti}_{3} \mathrm{Si}_{4} \mathrm{O}_{22}$ & $P 2_{1} / a$ & $13.328(10)$ & $5.727(4)$ & $10.971(8)$ & $100.91(6)$ & $822.3(10)$ & 10.773 & 2.0 & 3 \\
\hline $\mathrm{Nd}_{4} \mathrm{Co}_{2} \mathrm{Ti}_{3} \mathrm{Si}_{4} \mathrm{O}_{22}$ & $P 2_{1} / a$ & $13.325(4)$ & $5.706(2)$ & $10.998(2)$ & $100.82(6)$ & $821.3(4)$ & 10.803 & 2.0 & 3 \\
\hline $\mathrm{Nd}_{4} \mathrm{~V}_{5} \mathrm{Si}_{4} \mathrm{O}_{22}$ & $C 2 / m$ & $13.377(4)$ & $5.589(4)$ & $10.983(3)$ & $100.61(2)$ & $807(1)$ & 10.795 & 3.0 & 11 \\
\hline Chevkinite-(Ce) & $P 2_{1} / a$ & $13.382(15)$ & $5.735(6)$ & $11.061(12)$ & $100.629(3)$ & $834.3(16)$ & 10.871 & 1.81 & $16^{+}$ \\
\hline Chevkinite-(Ce) & $P 2_{1} / a$ & $13.444(4)$ & $5.7619(16)$ & $11.091(3)$ & $100.676(4)$ & $844.3(4)$ & 10.899 & 1.75 & $16^{+}$ \\
\hline $\mathrm{Pr}_{4} \mathrm{Mg}_{2} \mathrm{Ti}_{3} \mathrm{Si}_{4} \mathrm{O}_{22}$ & $P 2_{1} / a$ & $13.376(2)$ & $5.7074(7)$ & $11.016(2)$ & $100.71(1)$ & $826.3(2)$ & 10.824 & 1.95 & 2 \\
\hline $\mathrm{Pr}_{4} \mathrm{Ni}_{2} \mathrm{Ti}_{3} \mathrm{Si}_{4} \mathrm{O}_{22}$ & $P 2_{1} / a$ & $13.362(3)$ & $5.683(1)$ & $11.008(3)$ & $100.69(3)$ & $821.4(4)$ & 10.817 & 2.0 & 2 \\
\hline $\mathrm{Pr}_{4} \mathrm{~V}_{5} \mathrm{Si}_{4} \mathrm{O}_{22}$ & $C 2 / m$ & $13.410(2)$ & $5.5998(9)$ & $11.027(3)$ & $100.57(2)$ & $814.0(3)$ & 10.84 & 3.0 & 10 \\
\hline Christofschäferite-(Ce) & $P 2_{1} / m$ & $13.3722(4)$ & $5.7434(1)$ & $11.0862(2)$ & $100.580(2)$ & $836.97(3)$ & 10.898 & 1.43 & 13 \\
\hline Chevkinite-(Ce) & $P 2_{1} / a$ & $13.405(2)$ & $5.7489(7)$ & $11.081(1)$ & $100.614(1)$ & $839.3(2)$ & 10.891 & 1.97 & $16^{+}$ \\
\hline Dingdaohengite-(Ce) & $P 2_{1} / a$ & $13.466(2)$ & $5.7356(6)$ & $11.098(1)$ & $100.636(2)$ & $842.4(5)$ & 10.907 & 1.86 & 12 \\
\hline Chevkinite-(Ce) & $C 2 / m$ & $13.368(2)$ & $5.7243(6)$ & $11.041(1)$ & $100.516(1)$ & $830.7(2)$ & 10.856 & 1.78 & $8^{\ddagger}$ \\
\hline $\mathrm{La}_{3.4} \mathrm{Ca}_{0.6} \mathrm{~V}_{5} \mathrm{Si}_{4} \mathrm{O}_{22}$ & $C 2 / m$ & $13.448(4)$ & $5.5879(1)$ & $11.070(4)$ & $100.57(2)$ & $817.8(4)$ & 10.882 & 2.4 & 14 \\
\hline $\mathrm{La}_{4} \mathrm{~V}_{5} \mathrm{Si}_{4} \mathrm{O}_{22}$ & $C 2 / m$ & $13.510(3)$ & $5.605(1)$ & $11.114(2)$ & $100.45(3)$ & $827.6(3)$ & 10.930 & 3.0 & 15 \\
\hline Polyakovite-(Ce) & $C 2 / m$ & $13.398(1)$ & $5.6974(6)$ & $11.042(2)$ & $100.539(2)$ & $828.6(2)$ & 10.856 & 2.24 & 9 \\
\hline
\end{tabular}

*The empirical formula $\mathrm{REE}_{2.38} \mathrm{Ca}_{0.47} \mathrm{Sr}_{0.94} \mathrm{Ba}_{0.02} \mathrm{Na}_{0.12} \mathrm{Th}_{0.02} \mathrm{Fe}_{1.02} \mathrm{Mg}_{0.02} \mathrm{Mn}_{0.15} \mathrm{Al}_{0.04} \mathrm{Zr}_{0.49} \mathrm{Ti}_{3.29} \mathrm{Nb}_{0.03} \mathrm{Si}_{4.01} \mathrm{O}_{22}$ has been recalculated based on 22 anions, to achieve charge balance. The module charge is based on a B-site population of $\mathrm{Zr}_{0.49} \mathrm{Fe}_{0.36} \mathrm{Mn}_{0.15}$, in analogy to the site occupancies given in the paper. " “REE-rich” composition ${ }^{+}$Cell constants from neutron powder diffraction data. ${ }^{\ddagger}$ annealed crystal $3^{\text {an }}$

corresponding chevkinite unit cell of the perrierite structure refined in this work would hence have $c=10.9317 \AA$ and $\beta=101.08^{\circ}$, with the size of $a$ and $b$ unchanged.

To compare the metrics of the different members of the CGM, it is useful to calculate the distance between subsequent R-modules, which is tantamount to the (001) d-spacing, $d=c \sin \beta$. Figure 3 plots the resulting module separation against the calculated module charge for CGM and analogous synthetic compounds with known unit cell parameters. Calculating the module charge ideally requires knowledge of the chemical composition, the site occupancies and also of the oxidation state of the cations. While Sokolova et al. (2004) assumed for chevkinite-(Ce) that ferrous iron can only occupy the B position (or M1), even though they did not entirely rule out that mixed occupancy occurs also at the C- and D-sites, Nagashima et al. (2020) showed that ferrous and ferric iron can occupy the B-site (M1) and that ferrous iron is also present at the D-sites (M3, M4). If $\mathrm{Fe}^{3+}$ is present, we have, therefore, equally distributed it over all $\mathrm{Fe}$ containing sites. If necessary, empirical compositions have been recalculated from the oxide compositions based on 22 anions. CGM with unusually low oxide sums, significant vacancies or with potentially inaccurate unit cell dimensions have been omitted from Table 7 .

The interlayer spacing shown in Fig. 3 is close to the distance resulting from stacking four oxygen anions along $c^{*}$, i.e., $10.88 \AA$ (the horizontal dashed line in Fig 3). The perrierite structure type is found for smaller module 


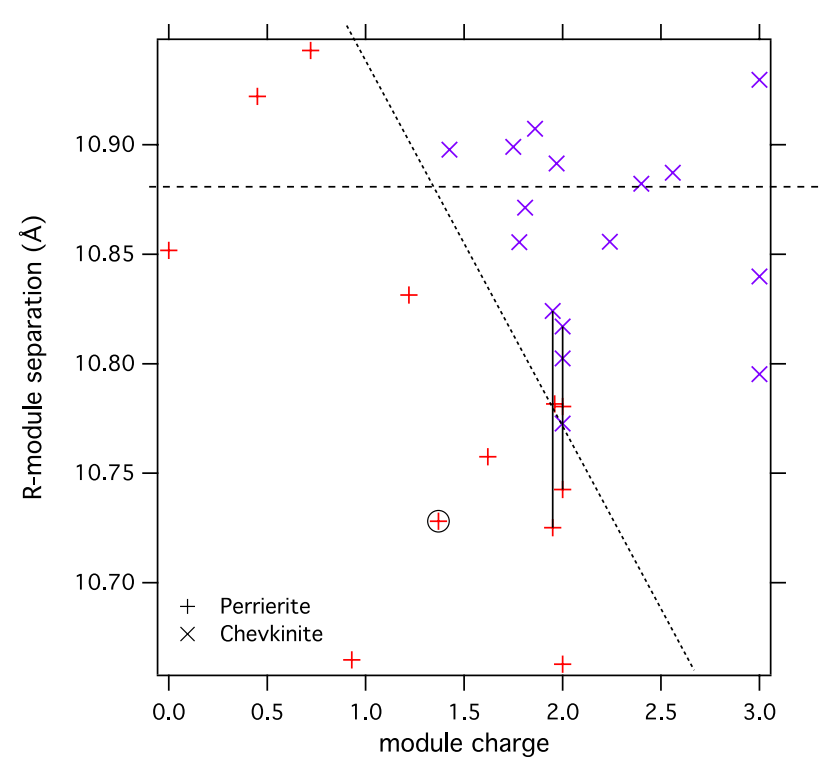

Fig. 3 Spacing between subsequent R-modules, $d_{(001)}$, as a function of module charge from Table 7. Red symbols denote perrierite-type structures (circled $=$ this work), blue symbols denote the chevkinitetype structures. The horizontal dashed line indicates the distance corresponding to the sum of four oxygen diameters. Vertical lines connect samples of identical composition transformed from the perrierite to the chevkinite structure by heat treatment (Ito and Arem 1971)

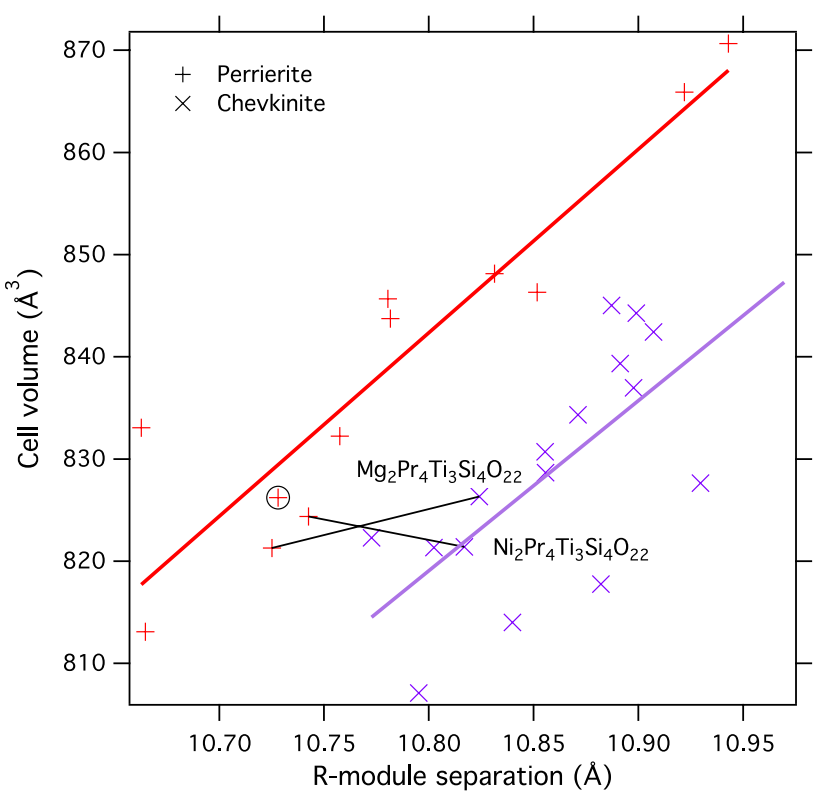

Fig. 4 Unit cell volume as a function of R-module separation. Red symbols denote perrierite-type structures (circled $=$ this work), blue symbols denote the chevkinite-type structures. Red and blue lines show the best fit to both sets of data, respectively. Black lines connect samples of identical composition transformed from the perrierite to the chevkinite structure by heat treatment (Ito and Arem 1971) charges at or below 2.0, while the chevkinite-type structure is observed at higher module charges, with the smallest value of 1.43 found for christofschäferite-(Ce). From this graph, it emerges that the perrierite module sequence is frequently associated with a smaller R-layer distance and smaller module charges than the chevkinite module sequence. An extreme example is matsubaraite, $\mathrm{Sr}_{4} \mathrm{Ti}_{5} \mathrm{O}_{8}$ $\left(\mathrm{Si}_{2} \mathrm{O}_{7}\right)_{2}$ (Miyajima et al. 2002), which has a nominal module charge of zero. The increase of the R-interlayer spacing from the perrierite to the chevkinite structure is also found for the two synthetic compounds studied by Ito and Arem (1971), with high- and low temperature polymorphs connected by vertical lines in Fig. 3. This indicates that, for a given chemical composition, the chevkinite module stacking inherently requires a larger size of the RSR layer stack than the perrierite module stacking. In addition, the separation of R-modules is of course influenced by other factors that influence the height of the S-module, especially the average size of the A-site cations. We might expect a positive correlation between R-module separation and unit cell volume. Plotting the latter against the former in Fig. 4 reveals a clear splitting between such positive correlations for the perrierite and the chevkinite module stacking. Chevkinites have an R-module separation that is, on average, about $0.14 \AA$ larger than that of perrierites with similar unit cell volume. This difference in module height can be almost entirely attributed to the $\mathrm{C}-\mathrm{O}$ bond that is normal to the (001) plane. This bond length ranges between 2.02 and $2.05 \AA$ (Sokolova et al. 2004; Nagashima et al. 2020) in most chevkinite-type structures. Taking the LSV perrierite- $(\mathrm{Ce})$ of this work as a representative of the perrierite-type structures, the equivalent $\mathrm{C}-\mathrm{O}$ distance is just $1.966 \AA$. Additional shortening of the height of the perrierite $\mathrm{CO}_{6}$ octahedra relative to the corresponding octahedra in chevkinite is caused by slight bending of the $\mathrm{O}-\mathrm{C}$ bonds with respect to the (001) plane. The $\mathrm{O}-\mathrm{C}-\mathrm{O}$ angle is $174.1^{\circ}$ in the LSV perrierite, while it is $180^{\circ}$ in chevkinite-(Ce) (Sokolova et al. 2004). In total, a difference of at least $0.11 \AA$ in $d_{(001)}$ results from the difference in $\mathrm{CO}_{6}$ height in both structures, accounting for almost $80 \%$ of the observed difference in R-module separation alone. Ultimately the larger module separation in the chevkinite structure type can be associated with its higher module charge, which is negative for the R-module, caused by lower positive charge of the $\mathrm{C}$ - and $\mathrm{D}$-cations at the center of this module, weakening the $\mathrm{C}-\mathrm{O}$ bonds normal to (001) and causing a more elongated octahedral environment parallel to the module stacking direction.

\section{Relation to empirical compositional trends}

The empirical compositional boundary between the perrierite and the chevkinite module sequence for CGM 
occurrences in rocks has been located along a line in a plot of $\mathrm{FeO}$ versus $(\mathrm{CaO}+\mathrm{SrO})$ content (Macdonald and Belkin 2002; Macdonald et al. 2019). The line extrapolates to an $\mathrm{FeO}$ content of about $4 \mathrm{wt} \%$ at zero wt $\%(\mathrm{CaO}+\mathrm{SrO})$ and reaches $15 \mathrm{wt} \% \mathrm{FeO}$ at about $10 \mathrm{wt} \%(\mathrm{CaO}+\mathrm{SrO})$. Compositions above this line apparently crystallize as chevkinite, those with lower $\mathrm{FeO}$ and higher $(\mathrm{CaO}+\mathrm{SrO})$ contents as perrierite. If we assume a simplified composition $\mathrm{Ce}_{4-x}$ $\mathrm{Ca}_{x} \mathrm{Fe}_{y} \mathrm{Ti}_{5-y} \mathrm{Si}_{4} \mathrm{O}_{22}$, the charge balance for the coupled substitution scheme $\mathrm{Ca}_{S}+\mathrm{Ti}_{R} \leftrightarrow \mathrm{Ce}_{S}+\mathrm{Fe}_{R}$ can be evaluated. Towards this aim, we assume that the B-site is fully occupied by $\mathrm{Fe}$, with Ti substitution occurring for $y<1$. Equations for $\mathrm{Fe}(y)$ as a function of $\mathrm{Ca}$ content $(x)$, based on charge balance for ferrous and ferric iron, respectively, can be calculated. Thus, we obtain $y=2-x / 2$ for $\mathrm{Fe}^{2+}$ and $y=4-x$ for $\mathrm{Fe}^{3+}$. The two resulting lines are plotted in Fig. 5 for $0 \leq x \leq 4$. The module charge above an Fe-content of 1 apfu increases linearly along these lines from bottom right to top left. All compositions corresponding to the above simplified formula can be expected to fall onto the two lines, with compositions containing $\mathrm{Fe}$ of mixed oxidation state expected to plot in the area between them. In the CGM, the presence of other metal cations, different substitution schemes or cation vacancies are obviously going to cause deviations, but generally the fields of perrierite and chevkinite structures shown in Fig. 5 are in qualitative agreement with those observed in natural samples. The crosses indicate positions of species shown in Table 7, excluding those like polyakovite-(Ce), that have Fe significantly substituted by other cations. The location of the dashed line in Fig. 5 is similar to that drawn by Macdonald et al. (2019). The oxide compositions at the intersections 1 and 2 amount to $3.65 \mathrm{wt} \% \mathrm{CaO}$ and 9.61 wt $\% \mathrm{FeO}$ and to $8.8 \mathrm{CaO}$ and $14.6 \mathrm{FeO}$, respectively. At both intersection points, the charge modulus of the R- and $\mathrm{S}$-modules is close to 1.25 .

Strontiochevkinite (Haggerty and Mariano 1983) does defy categorization by the above, however. To the authors' knowledge, no crystal structure refinement of this mineral exists to this day. The Debye-Scherrer powder diffraction data were indexed with a chevkinite-type unit cell by Haggerty and Mariano (1983). The electron microprobe analysis suggests an empirical composition of $\left(\mathrm{Sr}_{2.27} \mathrm{Ca}_{0.37} \mathrm{REE}_{1.29}\right.$ $\left.\mathrm{Na}_{0.02}\right)_{\sum=3.95}\left(\mathrm{Fe}_{0.913} \mathrm{Mn}_{0.02} \mathrm{Al}_{0.02} \mathrm{Zr}_{0.99} \mathrm{Cr}_{0.07} \mathrm{Ti}_{3.28}\right)_{\sum=5.29} \mathrm{Si}_{3.77}$ $\mathrm{O}_{22}$. This composition plots in the perrierite field of Fig. 5, in spite of the chevkinite-type unit cell data. There is also a deficit of Si and an excess of small cations beyond five apfu. This may indicate Ti substitution at the Si sites. But more importantly, it is impossible to predict which cation species occupy the B, C and D-sites, without structure analysis. Miyawaki et al. (2002) pointed out that the available powder

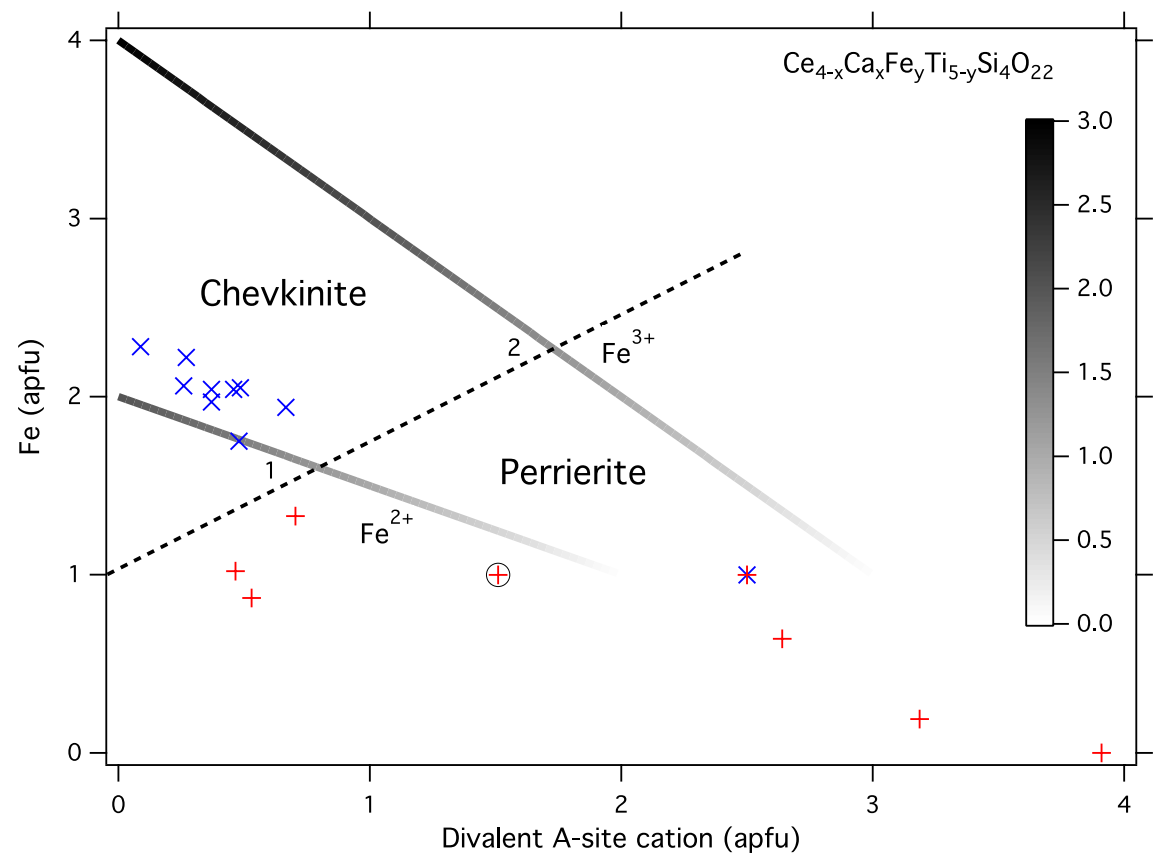

Fig. 5 Plot of Fe vs. divalent A-site cations $(\mathrm{Ca}, \mathrm{Sr})$ in atoms per formula unit for the simplified composition $\mathrm{Ce}_{4-x} \mathrm{Ca}_{x} \mathrm{Fe}_{y} \mathrm{Ti}_{5-y} \mathrm{Si}_{4} \mathrm{O}_{22}$. Lines describe the compositional variation obtained for divalent and trivalent $\mathrm{Fe}$ and the respective formal module charge as indicated by their grayscale. The broken line indicates the approximate position of the boundary between chevkinite- and perrierite-type structures. Symbols + and $\times$ mark the position of those samples in
Table 7 that are compatible with the simplified composition (circled $=$ this work). Position 1 corresponds to oxide composition (in $\mathrm{wt} \%$ ) $20.0 \mathrm{SiO}_{2}, 22.6 \mathrm{TiO}_{2}, 44.0 \mathrm{Ce}_{2} \mathrm{O}_{3}, 3.65 \mathrm{CaO}, 9.61 \mathrm{FeO}$, position 2 corresponds to $21.5 \mathrm{SiO} 2,19.5 \mathrm{TiO}_{2}, 33.0 \mathrm{Ce}_{2} \mathrm{O}_{3}, 8.8 \mathrm{CaO}, 14.6 \mathrm{FeO}$ (or $16.2 \mathrm{Fe}_{2} \mathrm{O}_{3}$ ). The coinciding + and $\times$ symbols indicate the position of strontiochevkinite 
diffraction data of strontiochevkinite could be indexed with a perrierite-type unit cell as well and that the material analyzed by Haggerty and Mariano (1983) might have been an Fe-rich rengeite.

We have so far observed that the module charge is larger in chevkinites and smaller in perrierites. One possible reason is that the perrierite structure with its strong out of center distortion of the D-site cation is stabilized if enough $\mathrm{Ti}$ or $\mathrm{Nb}$ is present to completely fill this site. An R-module charge at or below -2, as we postulate for the chevkinite structure increases the probability that some of the D-site Ti is substituted with a trivalent or even divalent cation. Lesser positive charge of the metal cations in the D-position would in turn also reduce repulsion with respect to the A-site cations and might thus stabilize the chevkinite structure type with its smaller, symmetrical D-A distances. Lower positive charge at the $\mathrm{C}$ and $\mathrm{D}$-sites of the R-module in the chevkinite structure type, corresponding to its higher absolute module charge, causes the expansion of this R-module, leading to the observed larger R-module separation in the chevkinite structure (Fig. 4).

\section{Space group symmetry of perrierite-(Ce)}

While the Laacher See perrierite-(Ce) crystallizes in $C 2 / m$ space group symmetry, many examples of perrierites (Table 7) with SG symmetry $P 2_{1} / a$ exist, notably the synthetic $\mathrm{La}_{4} \mathrm{Mg}_{2} \mathrm{Ti}_{3} \mathrm{O}_{8}\left(\mathrm{Si}_{2} \mathrm{O}_{7}\right)_{2}$ (Calvo and Faggiani 1974). The $P 2_{1} / a$ space group symmetry would manifest itself by the formation of reflections violating the

(a)

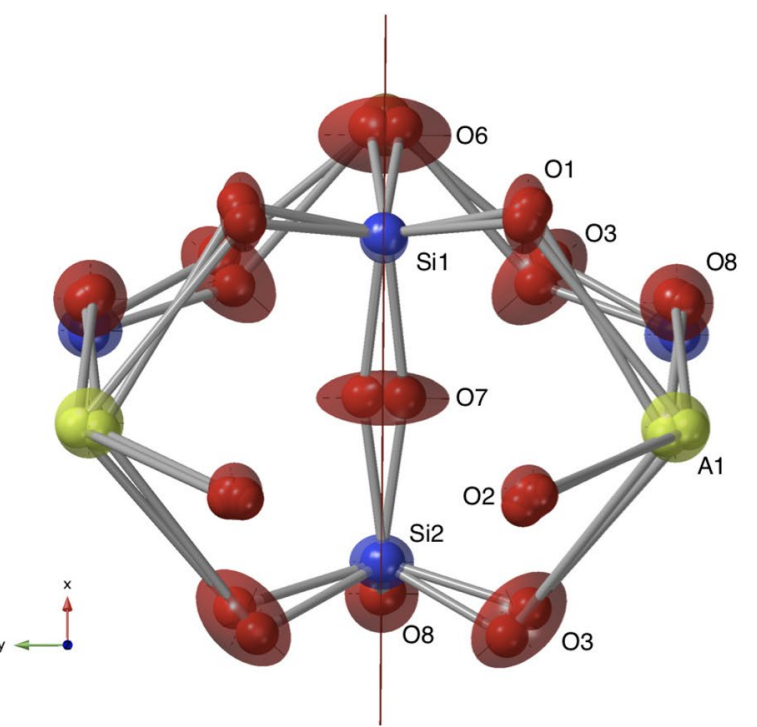

Fig. 6 Perrierite-(Ce) in SG C2/m (transparent ellipsoids with site labels) and superimposed structure of the distorted perrierite type $\mathrm{La}_{4} \mathrm{Mg}_{2} \mathrm{Ti}_{3} \mathrm{Si}_{4} \mathrm{O}_{22}$ (Calvo and Faggiani 1974) (ball \& stick model) in SG $P 2_{1} / a$. The vertical line marks the position of the mirror plane in condition for C-centering, $h+k=2 \mathrm{n}$. This is clearly not the case with the perrierite- $(\mathrm{Ce})$ of this study. However, the distortions of $\mathrm{La}_{4} \mathrm{Mg}_{2} \mathrm{Ti}_{3} \mathrm{O}_{8}\left(\mathrm{Si}_{2} \mathrm{O}_{7}\right)_{2}$ from $C 2 / m$ symmetry are small. Stachowicz et al. (2019b) showed that $C 2 / m$ chevkinite-(Ce) can be annealed at $750^{\circ} \mathrm{C}$ to obtain the $P 2_{1} / a$ symmetry, with some oxygen atoms showing the largest shifts away from the mirror plane that is present in $C 2 / m$. In Fig. 6, we show that the displacement ellipsoids obtained for the perrierite-(Ce) structure at room temperature encompass the atom positions of the distorted $\mathrm{La}_{4} \mathrm{Mg}_{2} \mathrm{Ti}_{3} \mathrm{O}_{8}\left(\mathrm{Si}_{2} \mathrm{O}_{7}\right)_{2}$ structure at the $95 \%$ probability level. This indicates that the distortions present in the $P 2_{1} / a$ structure of perrierite, notably a kinked $\mathrm{Si}-\mathrm{O}-\mathrm{Si}$ bridging bond, off the pseudo-mirror plane, as well as slight rotations of the $\mathrm{SiO}_{4}$ tetrahedra and displacements of the A-site cations parallel [010], are locally present within the $\mathrm{S}$-modules of perrierite-(Ce). The observed $C 2 / \mathrm{m}$ structure is the result of averaging over many such S-layers with out-of-phase distortions. Only if the distortions in a sufficiently long sequence of S-layers are in-phase, the $h+k=2 \mathrm{n}+1$ reflections develop and the structure can be refined in SG $P 2_{1} / a$. Locally, each R-layer may act as an antiphase domain boundary, separating S-layers with different sense of distortion. An ordered arrangement of the distortions across many layer packets could be obtained via heating, as it was shown by Stachowicz et al. (2019b) for similarly disordered chevkinite-(Ce), even though the partially metamict nature of their samples has to be considered in this context.

(b)

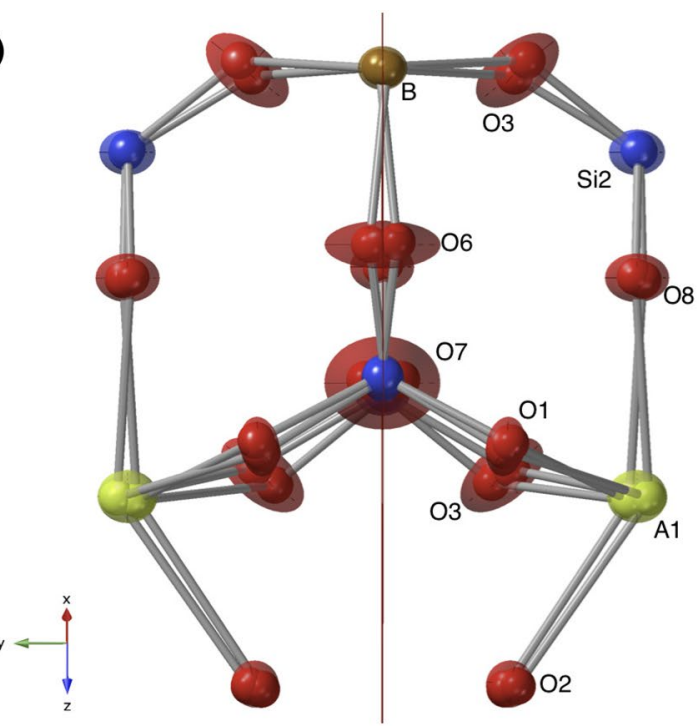

SG $C 2 / m$. The bridging oxygen of the sorosilicate group $(\mathrm{O} 7)$ is at the center of the plot, which is oriented parallel to the $\mathrm{Si}-\mathrm{O}-\mathrm{Si}$ bridge in (a) and normal to it in (b). Red color indicates oxygen atoms, for other colors see Fig. 2 
Table 8 Displacive mode amplitudes of perrierite-(Ce) calculated with Isodistort (Stokes et al. 2019), based on perrierite-(Ce) of this work as parent structure and $\mathrm{La}_{4} \mathrm{Mg}_{2} \mathrm{Ti}_{3} \mathrm{O}_{8}\left(\mathrm{Si}_{2} \mathrm{O}_{7}\right)_{2}$ of Calvo and Faggiani (1974) as hettotype structure. Only displacements with $d_{\max }>0.02 \AA$ are shown

\begin{tabular}{|c|c|c|}
\hline Mode & Amplitude & $d_{\max } \AA$ \\
\hline \multicolumn{3}{|l|}{$A_{g}$} \\
\hline $\mathrm{A} 1 \mathrm{~A}_{2}^{\prime}(\mathrm{a})$ & 0.05464 & 0.02732 \\
\hline $\mathrm{A} 2 \mathrm{~A}_{1}{ }_{1}(\mathrm{a})$ & -0.05976 & 0.02988 \\
\hline $\mathrm{D} \mathrm{A}_{1}^{\prime}(\mathrm{a})$ & 0.31392 & 0.15696 \\
\hline $\mathrm{DA} \mathrm{A}_{2}(\mathrm{a})$ & 0.06166 & 0.03083 \\
\hline $\mathrm{Si}_{1} \mathrm{~A}_{1}{ }_{1}(\mathrm{a})$ & -0.08610 & 0.04305 \\
\hline $\mathrm{Si}_{1} \mathrm{~A}_{2}^{\prime}(\mathrm{a})$ & 0.06415 & 0.03208 \\
\hline $\mathrm{Si} 2 \mathrm{~A}_{2}^{\prime}$ (a) & 0.04294 & 0.02147 \\
\hline $\mathrm{O} 1 \mathrm{~A}_{1}(\mathrm{a})$ & 0.10973 & 0.03880 \\
\hline $\mathrm{O} 4 \mathrm{~A}_{2}{ }_{2}$ (a) & 0.05142 & 0.02571 \\
\hline $\mathrm{O} \mathrm{A}_{1}{ }_{1}$ (a) & -0.04919 & 0.02459 \\
\hline $\mathrm{O} 6 \mathrm{~A}_{2}{ }_{2}$ (a) & 0.07988 & 0.03994 \\
\hline $\mathrm{O} 7 \mathrm{~A}_{1}{ }_{1}(\mathrm{a})$ & -0.08195 & 0.04097 \\
\hline $\mathrm{O} 7 \mathrm{~A}_{2}{ }_{2}$ (a) & 0.04244 & 0.02122 \\
\hline$A_{g}$ total & 0.40944 & \\
\hline \multicolumn{3}{|l|}{$Y_{2+}$} \\
\hline $\mathrm{C} \mathrm{B}_{1}(\mathrm{a})$ & 0.05218 & 0.02609 \\
\hline $\mathrm{C} \mathrm{B}_{2}$ (a) & -0.09736 & 0.04868 \\
\hline A1 A"(a) & 0.22368 & 0.11184 \\
\hline A2 A"(a) & 0.29937 & 0.14969 \\
\hline D A"(a) & 0.08021 & 0.04011 \\
\hline $\mathrm{O} 1 \mathrm{~A}_{1}(\mathrm{a})$ & 0.10027 & 0.03545 \\
\hline $\mathrm{O} 1 \mathrm{~A}_{2}(\mathrm{a})$ & -0.25065 & 0.08862 \\
\hline $\mathrm{O} 2 \mathrm{~A}_{3}(\mathrm{a})$ & 0.16375 & 0.05789 \\
\hline $\mathrm{O} 3 \mathrm{~A}_{1}(\mathrm{a})$ & -0.12956 & 0.04581 \\
\hline $\mathrm{O} 3 \mathrm{~A}_{2}(\mathrm{a})$ & 0.32479 & 0.11483 \\
\hline $\mathrm{O} 3 \mathrm{~A}_{3}(\mathrm{a})$ & 0.28038 & 0.09913 \\
\hline O4 A"(a) & 0.08699 & 0.04350 \\
\hline O5 A"(a) & -0.04632 & 0.02316 \\
\hline O6 A"(a) & 0.37054 & 0.18527 \\
\hline O7 A"(a) & -0.38070 & 0.19035 \\
\hline O8 A"(a) & -0.04067 & 0.02034 \\
\hline $\mathrm{Y}_{2+}$ total & 0.86972 & \\
\hline Overall & 0.96128 & \\
\hline
\end{tabular}

In terms of group-subgroup relations, $C 2 / m$ constitutes the parent symmetry and $P 2_{1} / a\left(P 2_{1} / c\right)$ constitutes the symmetry of the distorted phase. The distortions can be decomposed into mode amplitudes using the Isodistort program (Stokes et al. 2019). The results are shown in Table 8, where the LSV perrierite has been used as the parent structure and $\mathrm{La}_{4} \mathrm{Mg}_{2} \mathrm{Ti}_{3} \mathrm{O}_{8}\left(\mathrm{Si}_{2} \mathrm{O}_{7}\right)_{2}$ as the distorted structure. The largest mode amplitudes occur for the $\mathrm{Y}_{2+}$ mode at the zone boundary point $\mathrm{Y}$, corresponding to the $h+k=2 n+1$ positions of reciprocal space. We emphasize the importance of domain formation of the distorted $P 2_{1} / a$ crystal structure. The transition from $C 2 / m$ to $P 2_{1} / a$ symmetry would be displacive, with $Y_{2+}$ as the active irrep and $\mathrm{O} 7$, the bridging oxygen of the sorosilicate group, showing the largest displacement away from the $C 2 / m$ parent symmetry. As the phase transition would occur at the Brillouin zone boundary, it would be accompanied by formation of antiphase domains, related by a change of origin of $[1 / 2,1 / 2,0]$ according to the results of the Isodistort program. Figure 6 superimposes the coordination environments surrounding the bridging oxygen atom of two $\mathrm{Si}_{2} \mathrm{O}_{7}$-groups of the distorted $\mathrm{La}_{4} \mathrm{Mg}_{2}$ $\mathrm{Ti}_{3} \mathrm{O}_{8}\left(\mathrm{Si}_{2} \mathrm{O}_{7}\right)$ crystal structure related by such a vector $[1 / 2,1 / 2,0]$. As these two different orientations of the kinked $\mathrm{Si}-\mathrm{O}-\mathrm{Si}$ bridge closely resemble the displacement ellipsoids obtained in the $C 2 / m$ average structure, it is extremely likely that this average structure results from averaging over many such antiphase domains, related by the $[1 / 2,1 / 2,0]$ phase shift. Large domains, extending over tens or hundreds of RS layer packets, would give rise to reflections violating the $\mathrm{C}$-centering condition. The domains have to be rather small for these reflections to be absent, probably extending over just a few ordered RS layer packets, followed by an antiphase boundary. Formation of such microdomains could be attributed to rapid crystal growth in the stability field of the $P 2_{1} / a$ phase, or to rapid quenching through the phase transition. The latter case requires that the temperature of the phase transition is lower than the formation temperature of the perrierite crystals. For the chevkinite-(Ce) crystals studied by Stachowicz et al. (2019b), the equivalent phase transition temperature has to be higher than $750^{\circ} \mathrm{C}$, as this was the annealing temperature that stabilized the $P 2_{1} / a$ symmetry. In both scenarios, crystal growth and quenched microdomains, the domain boundaries are probably stabilized by cation disorder, especially REE-Ca disorder occurring at the A-sites.

\section{Conclusions}

In terms of composition, perrierite-(Ce) from the Laacher See volcano borders on the previously described perrierite-(La) from the same locality. It has $C 2 / m$ space group symmetry that is the macroscopic average of local antiphase domains of $P 2_{1} / a$ symmetry. The preferred formation of the perrierite-type module stacking for Ca-rich and $\mathrm{Fe}$-poor compositions can be related to their lower module charge.

The modular character of the CGM is of important consequence for the variability of the crystal structure and the composition of these minerals. While other polysomes than those conforming to the $1: 1$ proportion of $\mathrm{R}$ - and S-modules have so far only been synthesized, the 
existence of natural equivalents of such synthetic phases is expected. One obvious possibility is the insertion of additional R-modules, resulting in minerals of composition (REE, $\mathrm{Ca}, \mathrm{Sr})_{4} M\left(\mathrm{Si}_{2} \mathrm{O}_{7}\right)_{2}\left((\mathrm{Ti}, M) \mathrm{O}_{2}\right)_{4 m}$ with $M=\mathrm{Fe}$, $\mathrm{Al}, \mathrm{Zr}$ etc. and $m>1$, in analogy to the compounds synthesized by Wang et al. (1995). While the mixed valence $\mathrm{Ti}^{3+} / \mathrm{Ti}^{4+}$ compound $\mathrm{La}_{4} \mathrm{Ti}_{9} \mathrm{Si}_{4} \mathrm{O}_{30}$ and the rutile structure itself provide evidence for the possibility of RR stacking, it is not obvious how $\mathrm{S}$-modules could also occur in direct succession and whether there is a corresponding end member of the series. Nevertheless, other crystal structures composed of the two modules are possible in the form of more complex or disordered polytypes. Such polytypes could also involve microtwinning. An example is the orthorhombic rengeite described by Mashima et al. (2008). While we anticipate that the random stacking of S-layers with $[1 / 2,1 / 2,0]$ antiphase shifts causes the crystal structure to average to $C 2 / m$ symmetry, an ordered layer stacking in the sequence $\mathrm{RSRS}_{s} \mathrm{RS} \ldots$, where $\mathrm{S}_{s}$ is a module shifted by $[1 / 2,1 / 2,0]$ with respect to $S$ is possible too. This would then cause cell doubling in [001] direction and the pseudo-mirror plane of the averaged $C 2 / \mathrm{m}$ crystal structure would be replaced by a c-glide plane. Hence, the resulting symmetry can be expected to become C2/c. Crystals of composition $\mathrm{Ln}_{4} \mathrm{~V}_{5-x} \mathrm{Zn}_{x} \mathrm{O}_{8}\left(\mathrm{Si}_{2} \mathrm{O}_{7}\right)_{2}(\mathrm{Ln}$ $=\mathrm{La}, \mathrm{Ce}, \mathrm{Pr}$, and $\mathrm{Nd}$ ) with a similarly doubled chevkinitetype unit cell have been synthesized by Abeysinghe et al. (2016) and refined in space group $I 2 / a$, a different setting of $C 2 / c$. One possible hindrance to the discovery of such new members of the group is the frequent metamictization of the CGM. Recrystallized samples obtained by annealing may not represent the original structural state, and therefore, many more complex module sequences initially formed during natural crystal growth may have been irretrievably lost. Young formations of CGM, like those from the Eifel volcanic area used in this study, can aid the determination of crystal structures of commonly metamict and $\mathrm{X}$-ray amorphous minerals. One example not related to the CGM is the recent structure determination of samarskite(Y) (Britvin et al. 2019).

The modular nature of the CGM should also be considered for their nomenclature. Macdonald et al. (2019) already pointed out that the number of potential end members within the group would become unwieldy if the 50\% rule is applied to all structural sites. The fact that the perrierite and the chevkinite-type structures result from different module stacking, would somewhat reduce the need for an ever increasing number of mineral species, as the particular module sequence could be represented by addition of a suitable suffix and a species name would only be required to represent a particular composition, as it is common practice for other polysomatic series (Armbruster 2002).
Supplementary Information The online version contains supplementary material available at https://doi.org/10.1007/s00269-020-01130-6.

Acknowledgements The authors would like to thank Peter Stutz for sample preparation and Stefanie Heidrich for the electron microprobe analysis. Constructive comments provided by Thomas Armbruster and an anonymous reviewer helped to improve the manuscript.

Funding Open Access funding enabled and organized by Projekt DEAL.

Open Access This article is licensed under a Creative Commons Attribution 4.0 International License, which permits use, sharing, adaptation, distribution and reproduction in any medium or format, as long as you give appropriate credit to the original author(s) and the source, provide a link to the Creative Commons licence, and indicate if changes were made. The images or other third party material in this article are included in the article's Creative Commons licence, unless indicated otherwise in a credit line to the material. If material is not included in the article's Creative Commons licence and your intended use is not permitted by statutory regulation or exceeds the permitted use, you will need to obtain permission directly from the copyright holder. To view a copy of this licence, visit http://creativecommons.org/licenses/by/4.0/.

\section{References}

Abeysinghe D, Smith MD, Yeon J, Morrison G, Zur Loye H (2016) New lanthanide mixed-valent vanadium(III/IV) oxosilicates, $\mathrm{Ln}_{4} \mathrm{~V}_{5-x} \mathrm{Zn}_{x} \mathrm{Si}_{4} \mathrm{O}_{22}(\mathrm{Ln}=\mathrm{La}, \mathrm{Ce}, \mathrm{Pr}$, and Nd), crystallizing in a quasi two-dimensional rutile-based structure. Inorg Chem 55:1821-1830

Armbruster T (2002) Revised nomenclature of högbomite, nigerite, and taaffeite minerals. Eur J Mineral 14:389-395

Becker PJ, Coppens P (1974) Extinction within the limit of validity of the Darwin transfer equations. I. General formalism for primary and secondary extinction and their applications to spherical crystals. Acta Crystallogr A 30:129-147

Britvin SN, Pekov IV, Krzhizhanovskaya MG, Agakhanov AA, Ternes B, Schüller W, Chukanov NV (2019) Redefinition and crystal chemistry of samarskite-(Y), $\mathrm{YFe}^{3+} \mathrm{Nb}_{2} \mathrm{O}_{8}$ : cation-ordered niobate structurally related to layered double tungstates. Phys Chem Miner 46:727-741

Brown ID (2002) The chemical bond in inorganic chemistry - the bond valence model. Oxford University Press, Oxford

Calvo C, Faggiani R (1974) A re-investigation of the crystal structures of chevkinite and perrierite. Amer Mineral 59:1277-1285

Chen J, Guo G, Zhuang H, Huang J, Zhang Q (1995) $\mathrm{Pr}_{4} \mathrm{~V}_{5} \mathrm{Si}_{4} \mathrm{O}_{22}$ - a new praseodymium vanadium oxosilicate with chevkinite structure. J Solid State Chem 116(1):211-215

Chen J, Guo G, Zhuang H, Huang J, Zhang Q (1996) $\mathrm{Nd}_{4} \mathrm{~V}_{5} \mathrm{Si}_{4} \mathrm{O}_{22}$. Acta Crystallogr C 52:2125-2127

Chen SC, Ramanujachary KV, Greenblatt M (1994) $\mathrm{La}_{3.4} \mathrm{Ca}_{0.6} \mathrm{~V}_{5} \mathrm{Si}_{4} \mathrm{O}_{22}$ a novel mixed-valent vanadium (III/IV) oxosilicate. Inorg Chem 33:5994-5998

Chukanov NV, Aksenov SM, Rastsvetaeva RK, Belakovskiy DI, Göttlicher J, Britvin SN, Möckel S (2012a) Christofschäferite-(Ce), $(\mathrm{Ce}, \mathrm{La}, \mathrm{Ca})_{4} \mathrm{Mn}^{2+}\left(\mathrm{Ti}, \mathrm{Fe}^{3+}\right)_{3}\left(\mathrm{Fe}^{3+}, \mathrm{Fe}^{2+}, \mathrm{Ti}\right)\left(\mathrm{Si}_{2} \mathrm{O}_{7}\right)_{2} \mathrm{O}_{8}$ -a new chevkinite-group mineral from the Eifel area, Germany. Novye Dannye o Mineralakh 47:33-42

Chukanov NV, Blass G, Pekov IV, Belakovskiy DI, Van KV, Rastsvetaeva RK, Aksenov SM (2012b) Perrierite-(La), $(\mathrm{La}, \mathrm{Ce}, \mathrm{Ca})_{4}\left(\mathrm{Fe}^{2+}, \mathrm{Mn}\right)\left(\mathrm{Ti}, \mathrm{Fe}^{3+}, \mathrm{Al}\right)_{4}\left(\mathrm{Si}_{2} \mathrm{O}_{7}\right)_{2} \mathrm{O}_{8}$, a new mineral species from the Eifel volcanic district, Germany. Geol Ore Deposit 54:647-655 
Ferraris G, Makovicky E, Merlino S (2004) Crystallography of Modular Materials, IUCr Monographs on Crystallography, vol 15. Oxford University Press, Oxford

Gottardi G (1960) The crystal structure of perrierite. Amer Mineral 45:1-14

Gueho C, Giaquinta D, Mansot JL, Ebel T, Palvadeau P (1995) Structure and magnetism of $\mathrm{La}_{4} \mathrm{Mn}_{5} \mathrm{Si}_{4} \mathrm{O}_{22}$ and $\mathrm{La}_{4} \mathrm{~V}_{5} \mathrm{Si}_{4} \mathrm{O}_{22}$ : Two new rare-earth transition metal sorosilicates. Chem Mater 7:486-492

Haggerty SE, Mariano AN (1983) Strontian-loparite and strontiochevkinite: Two new minerals in rheomorphic fenites from the Paraná basin carbonatites, South America. Contrib Mineral Petrol 84:365-381

Ito J (1967) A study of chevkinite and perrierite. Amer Mineral 52:1094-1104

Ito J, Arem JE (1971) Chevkinite and perrierite: synthesis, crystal growth and polymorphism. Amer Mineral 56:307-319

Macdonald R, Bagiński B, Belkin HE, Stachowicz M (2019) Composition, paragenesis, and alteration of the chevkinite group of minerals. Amer Mineral 104:348-369

Macdonald R, Belkin HE (2002) Compositional variation in minerals of the chevkinite group. Mineral Mag 66:1075-1098

Mashima H, Akai J, Nakamuta Y, Matsubara S (2008) Orthorhombic polymorph of rengeite from Ohmi region, central Japan. Amer Mineral 93:1153-1157

Miyajima H, Matsubara R, Miyawaki R, Yokoyama K, Hirokawa $\mathrm{K}$ (2001) Rengeite, $\mathrm{Sr}_{4} \mathrm{ZrTi}_{4} \mathrm{Si}_{4} \mathrm{O}_{22}$, a new mineral, the $\mathrm{Sr}-\mathrm{Zr}$ analogue of perrierite from the Itoigawa-Ohmi district, Niigata prefecture, central Japan. Mineral Mag 65:111-120

Miyajima $\mathrm{H}$, Miyawaki $\mathrm{R}$, Ito $\mathrm{K}$ (2002) Matsubaraite, $\mathrm{Sr}_{4} \mathrm{Ti}_{5}\left(\mathrm{Si}_{2} \mathrm{O}_{7}\right)_{2} \mathrm{O}_{8}$, a new mineral, the $\mathrm{Sr}-\mathrm{Ti}$ analogue of perrierite in jadeitite from the Itoigawa-Ohmi district, Niigata prefecture, Japan. Eur J Mineral 14:1119-1128

Miyawaki R, Matsubara S, Miyajima H (2002) The crystal structure of rengeite, $\mathrm{Sr}_{4} \mathrm{ZrTi}_{4}\left(\mathrm{Si}_{2} \mathrm{O}_{7}\right)_{2} \mathrm{O}_{8}$. J Miner Petrol Sci 97:7-12

Nagashima M, Armbruster T, Akasaka M, Sano-Furukawa A, NishioHamane D, Malsy A, Imaoka T, Nakashima K (2020) Multimethodical study of the $\mathrm{Ti}, \mathrm{Fe}^{2+}$ and $\mathrm{Fe}^{3+}$ distribution in chevkinite-subgroup minerals: X-ray diffraction, neutron diffraction, ${ }^{57} \mathrm{Fe}$ Mössbauer spectroscopy and electron-microprobe analyses. Phys Chem Miner 47(6):29

Palmer D (2015) Visualization and analysis of crystal structures using CrystalMaker software. Z Kristallogr 230:559-572

Petříček V, Dušek M, Palatinus L (2014) Crystallographic computing system JANA2006: General features. Z Kristallogr 229:345-352

Popov VA, Pautov LA, Sokolova E, Hawthorne FC, McCammon C, Bazhenova LF (2001) Polyakovite-(Ce), (REE, Ca) $)_{4}\left(\mathrm{Mg}, \mathrm{Fe}^{2+}\right)$ $\left(\mathrm{Cr}^{3+}, \mathrm{Fe}^{3+}\right)_{2}(\mathrm{Ti}, \mathrm{Nb})_{2} \mathrm{Si}_{4} \mathrm{O}_{22}$, a new metamict mineral species from the Ilmen mountains, Southern Urals, Russia: mineral description and crystal chemistry. Can Mineral 39:1095-1104

Schmitt AK, Wetzel F, Cooper KM, Zou H, Wörner G (2010) Magmatic Longevity of Laacher See Volcano (Eifel, Germany) Indicated by U-Th Dating of Intrusive Carbonatites. J Petrol 51:1053-1085

Schreurs AMM, Xian X, Kroon-Batenburg LMJ (2010) EVAL15: a diffraction data integration method based on ab initio predicted profiles. J Appl Crystallogr 43:70-82

Sokolova E, Hawthorne FC, Della Ventura G, Kartashov PM (2004) Chevkinite-(Ce): crystal structure and the effect of moderate radiation-induced damage on site-occupancy refinement. Can Mineral 42:1013-1025

Stachowicz M, Bagiński B, Macdonald R, Kartashov PM, Ozieblo A, Wozniak K (2014) Structure of Sr-Zr-bearing perrierite-(Ce) from the Burpala massif. Russia Mineral Mag 78(7):1647-1659

Stachowicz M, Bagiński B, Welch MD, Kartashov PM, Macdonald R, Balcerzak J, Tyczkowski J, Wozniak K (2019) Cation ordering, valence states, and symmetry breaking in the crystal-chemically complex mineral chevkinite-(Ce): X-ray diffraction and photoelectron spectroscopy studies and mechanisms of $\mathrm{Nb}$ enrichment. Amer Mineral 104:595-602

Stachowicz M, Welch MD, Bagiński B, Kartashov PM, Macdonald R, Wozniak K (2019) Cation ordering, valence states and symmetry breaking in the crystal-chemically complex mineral chevkinite(Ce): Recrystallization, transformation, and metamict states of chevkinite. Amer Mineral 104:1481-1486

Stokes HT, Hatch DM, Campbell BJ (2019) Isodistort, isotropy software suite. iso.byu.edu

Wang S, Hwu S, Paradis JA, Whangbo M (1995) $\alpha$ - and $\beta$ $\mathrm{La}_{4} \mathrm{Ti}_{9} \mathrm{Si}_{4} \mathrm{O}_{30}$ : Synthesis and structure of the second member $(\mathrm{m}=2)$ of novel layered oxosilicates containing $(110)$ rutile sheets. electrical property and band structure characterization of the mixed-valence titanium (III/IV) oxosilicate series, $\mathrm{La}_{4} \mathrm{Ti}\left(\mathrm{Si}_{2} \mathrm{O}_{7}\right)_{2}\left(\mathrm{TiO}_{2}\right)_{4 m}(\mathrm{~m}=1,2)$. J Am Ceram Soc 117:5515-5522

Xu J, Yang G, Li G, Wu Z, Shen G (2008) Dingdaohengite-(Ce) from the Bayan Obo REE-Nb-Fe mine, China: Both a true polymorph of perrierite-(Ce) and a titanic analog at the $\mathrm{C} 1$ site of chevkinite subgroup. Amer Mineral 93:740-744

Yang Z, Giester G, Ding K, Tillmanns E (2012) Hezuolinite, $(\mathrm{Sr}, \mathrm{REE})_{4} \mathrm{Zr}\left(\mathrm{Ti}, \mathrm{Fe}^{3+}, \mathrm{Fe}^{2+}\right)_{2} \mathrm{Ti}_{2} \mathrm{O}_{8}\left(\mathrm{Si}_{2} \mathrm{O}_{7}\right)_{2}$, a new mineral species of the chevkinite group from Saima alkaline complex, Liaoning province, NE China. Eur J Mineral 24:189-196

Publisher's Note Springer Nature remains neutral with regard to jurisdictional claims in published maps and institutional affiliations. 